\author{
MATTHEW D. SHAPIRO
}

Yale University

\title{
Investment, Output, and the Cost of Capital
}

ONE OF THE BEST-ESTABLISHED FACTS in macroeconomics is that business fixed investment and output move strongly together over the business cycle. By contrast, investment and the cost of capital are either uncorrelated or only weakly correlated. These relationships might appear to suggest that business fixed investment can be best explained by an accelerator model of investment, whereby investment responds to changes in the desired capital stock, itself determined by the demand for output. The theory behind the accelerator model is akin to the man-onthe-street view that firms have little incentive to invest when current prospects for selling the output produced by the new capital are relatively poor.

The claim that the correlation of output and investment is due to demand shocks provides a challenge to neoclassical and neo-Keynesian theories alike. Neoclassical theories of investment view output as the consequence of firms' choice of capital stock and other factors, not the cause. Put another way, if the neoclassical model is correct, firms should use prices and not quantities as signals in making their investment decisions. The observation that investment and output are strongly correlated while the cost of capital has little correlation with investment weighs against the neoclassical model.

I gratefully acknowledge the helpful comments of members of the Brookings Panel and participants in seminars at Chicago University and Yale. This research is supported in part by National Science Foundation Grant No. SES-8521791. 
Neo-Keynesians should not, however, find comfort in this embarrassment of neoclassical theory. The textbook $I S-L M$ model is also inconsistent with the empirical finding that output shocks rather than cost-of-capital shocks determine investment. If the interest rate does not affect investment, then the $I S$ curve is vertical, and there is no role for the Keynesian transmission mechanism from money to output. ${ }^{1}$

Understanding the role of prices and quantities in investment demand is important for academic macroeconomists. The strong cyclicality of fixed investment is one of the major characteristics of the business cycle, and business-cycle theory should be able to explain it. But the debate is more than academic. Economists often recommend increasing investment by reducing the cost of capital through tax incentives such as accelerated depreciation and the investment tax credit. Anyone making such recommendations should be able to explain why output shocks seem so much more important in investment dynamics than price shocks. Without a suitable explanation of these dynamics, the common policy recommendation appears to have little merit. Indeed, if output determines investment instead of the capital stock determining output, investment incentives will only induce firms to substitute capital for labor, rather than expanding capacity to produce.

That investment cannot be explained by the cost of capital has not gone unnoticed. The nation's best-selling macroeconomics text includes the following passage:

At least on evidence through 1979, it seems that the cost of capital empirically does not much affect investment and that accordingly the simple accelerator model does as well as the neoclassical model at explaining investment. ${ }^{2}$

The authors of the textbook, Rudiger Dornbusch and Stanley Fischer, speculate that the large changes in the cost of capital experienced in the early 1980s might help identify the effect of the cost of capital on investment. Unfortunately, this has not been the case. ${ }^{3}$ Peter K. Clark,

1. One could argue that the Keynesian transmission mechanism could be resurrected by letting the interest rate channel work through housing and consumer durables rather than fixed investment. (This channel makes housing do much of the work in explaining the 1982 recession: durable consumption rose from the peak business-cycle year of 1980 to the trough year of 1982.)

2. Rudiger Dornbusch and Stanley Fischer, Macroeconomics, 3d ed. (McGraw-Hill, 1984), pp. 222-23.

3. Barry Bosworth examines the early 1980 s in detail and finds little support for the hypothesis that the cost of capital affects investment. See Barry Bosworth, "Taxes and 
upon whose thorough comparison of the accelerator and neoclassical models Dornbusch and Fischer rely, concludes that aggregation problems and slow adjustment of the capital stock, rather than a defect of the theory, account for the poor performance of the neoclassical model. ${ }^{4}$

The claim that changes in the cost of capital do little to promote investment is also to be found in the business press:

Studies of capital investment since 1981 , however, reveal no clear-cut proof that the incentives worked. Many economists argue that the growth in investment since 1981 has been due more to economic expansion than to the incentives. ${ }^{5}$

In this paper, I shall adopt an alternative interpretation of the correlation between output and investment and show that there remains an identifiable and important role for the cost of capital in determining investment.

In my investigation of that role, I model investment as the consequence of a firm's choice of the capital stock that maximizes the present value of profits. Hence, the firm's capital accumulation decision is linked to its production technology. Investment is the process of adjusting the capital stock to its desired level. Changes in long-run capital stock are driven by changes in the relative cost of capital and by shocks to technology and labor supply. The investment path that firms undertake to achieve the desired changes in the capital stock will be determined by the cost of adjusting the capital stock. Hence, the capital stock, and not the rate of investment, is the appropriate primitive in analyzing firms' accumulation decisions. ${ }^{6}$

The firm will face random, persistent output shocks. A positive productivity shock may raise both output and the marginal product of capital. Productivity shocks can potentially explain the strong correla-

the Investment Recovery," BPEA, 1:1985, pp. 1-38. The statistical work in this study included data through the third quarter of 1985. The dynamics of investment differ little when they are analyzed excluding post- 1980 data. The period had high real interest rates and large reductions in the after-tax purchase price of capital through the provisions of the Economic Recovery Tax Act of 1981. High interest rates and tax-based investment incentives affect the cost of capital in opposite directions, so perhaps one should not be surprised that this period is not a big help in identifying an effect of the cost of capital.

4. Peter K. Clark, "Investment in the 1970s: Theory, Performance, and Prediction," BPEA, 1:1979, p. 104.

5. See Marc Levinson, “The Shaky Case for Aiding Investment,"' Dun's Business Month (March 1986), p. 22. Levinson cites a number of academic papers to support his claim.

6. See Lawrence H. Summers, "Requiem for the Investment Equation" (Harvard University, 1985). 
tion of investment and output and the weaker correlation of investment and the cost of capital. Insofar as productivity shocks are an important source of the parallel movement of output and investment, the "wrong" correlation of interest rates and investment may be induced in the datathat is, interest rates and investment could rise simultaneously_-because productivity shocks should raise interest rates. ${ }^{7}$ If changes in interest rates arise because of a mixture of pure cost-of-capital shocks and productivity shocks, the zero correlation between investment and interest rates might obtain. ${ }^{8}$ The methodology in this paper permits identification of the pure cost-of-capital effect. The standard identification problem in simultaneous equations econometrics may account for the failure of investment equations to find an important cost-of-capital coefficient.

Note that aggregate demand shocks, such as an autonomous increase in businessmen's assessment of the profitability of investment, will also lead to the same positive correlation of investment and interest rates. ${ }^{9}$ Demand shocks will affect the demand for labor, and changes in labor account for much of the variance of changes in output. Moreover, demand for capital is linked with the demand for labor. Thus, to characterize fully the movements of output and capital formation, I must also account for movements in labor. My specification of the labor market is fairly unrestrictive and will be consistent with either instantaneous labor market clearing and inelastic labor supply or nominal rigidities in the labor market that may keep workers off their labor supply curves at least for some time. ${ }^{10}$

The plan of the paper is as follows. First, I outline the theoretical model. Second, I give some nonstructural estimates of the dynamics of investment, output, and related variables. These estimates summarize

7. See Olivier J. Blanchard and Lawrence H. Summers, "Perspectives on High World Real Interest Rates," BPEA, 2:1984, pp. 273-324.

8. Productivity shocks can also be the source of the procyclicality (or acyclicality if there are other factors) of real wages.

9. These are the autonomous $I S$ shifts of the standard textbook Keynesian model. Animal spirits do not enter the model per se, but the autonomous deviations of labor supply from labor demand discussed here play the same role by creating a channel for aggregate demand to affect investment.

10. I will not be able to say what fraction of shocks to output come from shocks to supply or demand because I will be unable to tell what fraction of the labor shock is due to shifts in the supply of labor. Yet I will be able to address the issue of what fraction of measured productivity shocks is potentially attributable to labor shocks. 
the facts that serve as an impetus for this study and document the raw correlations of the data that any valid model must mimic. Subsequent sections discuss the predictions and policy implications of the model. The final section summarizes and evaluates the findings of the paper.

\section{A Model of Capital Formation}

In this section, I outline a model of the investment process to account for the joint dynamics of output, investment, and the cost of capital. The firms will not be constrained in the output market, yet the model will generate the investment-output correlations discussed above and documented below.

As already discussed, neoclassical and neo-Keynesian theories of investment, with either adjustment costs or delivery lags, give primary explanatory power for changes in investment to changes in factor prices and investors' required rate of return. ${ }^{11}$ In theories based on Tobin's $q$, the ratio of market value to replacement cost of capital, factor cost is likewise the key determinant of investment. ${ }^{12}$ Indeed, the neoclassical theory is equivalent to the $q$ theory when the production function has quadratic costs of adjustment and obeys certain regularity conditions such as constant returns to scale. ${ }^{13}$ As noted, the correlation of output and investment is, on its face, difficult to reconcile with these theories.

In the model, the representative firm maximizes the present discounted value of profits, taking input and output prices and investors' required rate of return as given. The firm has a production function relating labor,

11. Dale W. Jorgenson, "Capital Theory and Investment Behavior," American Economic Review, vol. 53 (May 1963, Papers and Proceedings, 1962), pp. 247-59; Robert E. Hall and Dale W. Jorgenson, "Tax Policy and Investment Behavior," American Economic Review, vol. 57 (June 1967), pp. 391-414; Robert E. Lucas and Edward C. Prescott, "Investment Under Uncertainty," Econometrica, vol. 39 (September 1971), pp. 659-81. For some recent estimates, see Matthew D. Shapiro, "The Dynamic Demand for Capital and Labor,"' Quarterly Journal of Economics, forthcoming.

12. James Tobin, "A General Equilibrium Approach to Monetary Theory,' Journal of Money, Credit and Banking, vol. 1 (February 1969), pp. 15-29; Andrew B. Abel, Investment and the Value of Capital (Garland, 1979); Lawrence H. Summers, "Taxation and Corporate Investment: A $q$-Theory Approach," BPEA, 1:1981, pp. 67-127; Fumio Hayashi, "Tobin's Marginal $q$ and Average $q$ : A Neoclassical Approach,"'Econometrica, vol. 50 (January 1982), pp. 213-24.

13. See Hayashi, "Tobin's Marginal $q$ and Average $q$." 
capital, and investment to output. Investment enters to allow for costs of adjusting the capital stock measured as forgone output. Shocks that increase output by increasing productivity will also increase the marginal product of capital and hence increase investment demand. Observed output shocks will be decomposed into labor shocks and productivity shocks.

The model is related to two recent lines of research. First, it follows Finn Kydland, Edward Prescott, John Long, and Charles Plosser in suggesting that productivity shocks are an important element in businesscycle dynamics. ${ }^{14}$ Unlike some contributions to the real business-cycle literature, my work does not suggest that all output fluctuations are caused by productivity shocks. Second, the model adopts Charles Nelson and Plosser's characterization of the nature of macroeconomic shocks. ${ }^{15}$ Nelson and Plosser cannot reject the presence of unit roots in many economic time series. Gregory Mankiw and John Campbell demonstrate that changes in GNP are very persistent, so the unit root is quantitatively important. ${ }^{16}$ The supply shocks in the model appear to have a permanent component that corresponds to a unit root in the time series for productivity and accounts for the persistence of the correlation of output and investment. Presumably, much of invention and innovation is permanent, so it is natural to think of productivity shocks as having an important permanent component. There may also be a positive drift to the productivity shocks arising from steady technological progress. By allowing for unit roots, I avoid the common practice of studying business-cycle fluctuations as deviations from a deterministic trend. The practice of routinely detrending data can induce spurious cycles in the data. ${ }^{17}$

14. Finn E. Kydland and Edward C. Prescott, "Time to Build and Aggregate Fluctuations," Econometrica, vol. 50 (November 1982), pp. 1345-70; and John B. Long, Jr., and Charles I. Plosser, "Real Business Cycles," Journal of Political Economy, vol. 91 (February 1983), pp. 39-69.

15. Charles R. Nelson and Charles I. Plosser, "Trends and Random Walks in Macroeconomic Time Series: Some Evidence and Implications,' Journal of Monetary Economics, vol. 10 (September 1982), pp. 139-62.

16. John Y. Campbell and N. Gregory Mankiw, "Are Output Fluctuations Transitory?” (National Bureau of Economic Research, 1986).

17. See Charles R. Nelson and Heejoon Kang, "Spurious Periodicity in Inappropriately Detrended Time Series Data," Econometrica, vol. 49 (May 1981), pp. 741-51; Charles R. Nelson and Heejoon Kang, "Pitfalls in the Use of Time as an Explanatory Variable in Regression,'” Journal of Business and Economic Statistics, vol. 2 (January 1984), pp. 73- 
Studying the role of supply shocks in economic dynamics has many precedents. In a seminal paper, Robert Solow decomposes output into two parts: that explained by input and a residual. Edward Denison and others extend Solow's framework to account for the sources of growth. Yet, about 50 percent of the change in output is unaccounted for by changes in the quantity or quality of input. ${ }^{18}$ This residual productivity shock, or trend, is sometimes regarded as important only for understanding long-term growth, as though the business cycle can be analyzed independently of these long-term phenomena. ${ }^{19}$ Although Joseph Schumpeter saw innovation as the primary engine of medium-term fluctuations in 1934, only recently have modern macroeconomists begun to offer theories in which productivity shocks drive the business cycle. ${ }^{20}$ The statistical finding that most economic time series have unit roots gives impetus to the view that one should not arbitrarily separate shortrun and long-run fluctuations. Of course, frictions such as cost of adjustment and long-term contracts cause short-run and long-run outcomes to differ. These frictions should be built into models so that the difference between short-run and long-run responses to shocks arises endogenously.

The supply shocks I have in mind are much broader than the relentless, and presumably positive, technological change of the Solow growth model, though they would include technological breakthroughs such as

82; and N. Gregory Mankiw and Matthew D. Shapiro, "Trends, Random Walks, and Tests of the Permanent Income Hypothesis," Journal of Monetary Economics, vol. 16 (September 1985), pp. 165-74.

18. Robert M. Solow, "Technical Change and the Aggregate Production Function," Review of Economics and Statistics, vol. 39 (August 1957), pp. 312-20; Edward F. Denison, Accounting for United States Economic Growth, 1929-1969 (Brookings, 1974). See Edward C. Prescott, "Theory Ahead of Business Cycle Measurement," CarnegieRochester Conference Papers (1985), for a discussion of the relation of growth accounting to business-cycle analysis and measurement.

19. This is the common justification for detrending economic time series prior to analyzing them in much of macroeconomic research.

20. See Joseph Schumpeter, The Theory of Economic Development: An Inquiry into Profits, Capital, Interest, and the Business Cycle (Harvard University Press, 1934). See also a discussion of the business-cycle theories of Spiethoff by Gottfried Haberler, Prosperity and Depression: A Theoretical Analysis of Cyclical Movements, 3d ed. (Geneva: League of Nations, 1941), especially pp. 80ff. Productivity shocks also play a crucial role in recent industrial organizational models of the cycle. See, for example, Andrei Shleifer, “Implementation Cycles”' (Massachusetts Institute of Technology, 1985). 
the development of the transistor. Negative productivity shocks would include such things as the effect of increased environmental protection on the generation of nuclear power, the depreciation of asbestos manufacturers' capital due to the discovery of the health hazard, the loss of value of capital services to chemical companies after the Bhopal disaster, the institution of the fifty-five-mile-per-hour speed limit, and the virtually permanent loss of agricultural land following a large-scale nuclear disaster.

Much of the Brookings Panel's work during the 1970s and 1980s has concerned incorporating supply factors into the Keynesian model. The focus has been on price dynamics, but the models on which the work has been based certainly carry implications for output and consequently investment. ${ }^{21}$ Additionally, Hendrick Houthakker has presented evidence to the panel that, at the industry level, price and quantity move in opposite directions. The suggestion is that supply shocks are more important than demand shocks. ${ }^{22}$

\section{THE MODEL}

Consider a representative firm that maximizes the expected present discounted value of real after-tax profits. The firm takes prices as given and maximizes over its choice of inputs. This choice of inputs implies a level of output. The objective function of the firm is hence

$$
E_{t} \sum_{i=0}^{\infty} \tilde{R}_{t+i}\left\{\left(1-\tau_{t+i}\right) f\left(K_{t+i-1}, I_{t+i}, L_{t+i}, \epsilon_{t+i}\right)-w_{t+i} L_{t+i}-p_{t+i} I_{t+i}\right\},
$$

where $f\left(K_{t-1}, I_{t}, L_{t}, \epsilon_{t}\right)$ is the production function; $\tau_{t}$ the statutory corporate income tax rate; $w_{t}$ the real after-tax wage; $p_{t}$ the real aftertax purchase price of capital; and $K_{t-1}, I_{t}$, and $L_{t}$ are the capital stock, investment, and labor, respectively. The symbol $E_{t}$ denotes expectations taken conditionally on information known at time $t$ or earlier. The variable $\epsilon_{t}$ is a productivity shock. The $\tilde{R}_{t+i}$ is the $t$-period discount rate,

21. See, for example, Robert J. Gordon, "Can the Inflation of the 1970s Be Explained?" BPEA, 1:1977, pp. 253-77. Gordon estimates a Phillips curve that includes productivity shocks (measured by deviation of measured productivity from trend).

22. Hendrick S. Houthakker, "Growth and Inflation: Analysis by Industry," BPEA, 1:1979, pp. 241-56. 
which is time varying and random. It is the product of the one-period discount rate, $R_{t}$. The one-period rate is measured as the reciprocal of investors' gross one-period after-tax required rate of return. Output is a function of the lagged capital stock to account for delivery lags in the investment process. Hence, investment in one period does not become productive uritil the next period. Investment enters the production function to account for costs of adjusting the capital stock. Increasing investment, holding other inputs constant, reduces output. ${ }^{23}$

The firm solves the optimization problem given in equation 1 . That is, it maximizes the present discounted value of real after-tax profits. The choice variables of the firms at time $t$ are the current capital stock, $K_{t}$, and the current labor input, $L_{t}$. The firm maximizes equation 1 with respect to these variables, yielding the following stochastic first-order conditions:

$$
\begin{gathered}
E_{t}\left\{\left(1-\tau_{t}\right) f_{2}\left(K_{t-1}, I_{t}, L_{t}, \epsilon_{t}\right)-\rho_{t}\right. \\
+\left(1-\tau_{t+1}\right) R_{t+1}\left[f_{1}\left(K_{t}, I_{t+1}, L_{t+1}, \epsilon_{t+1}\right)\right. \\
\left.\left.-(1-\delta) f_{2}\left(K_{t}, I_{t+1}, L_{t+1}, \epsilon_{t+1}\right)\right]+R_{t+1}(1-\delta) p_{t+1}\right\}=0 \\
E_{t}\left\{\left(1-\tau_{t}\right) f_{3}\left(K_{t-1}, I_{t}, L_{t}, \epsilon_{t}\right)-w_{t}\right\}=0 .
\end{gathered}
$$

Here $\delta$ is the constant rate of depreciation of the capital stock. The equations state that expected after-tax marginal product equals marginal cost. The equation for capital is intertemporal because of the adjustment costs and delivery lags. Note that the marginal product of investment, which is negative, enters at both time $t$ and time $t+1$. Any path for the inputs must satisfy these equations.

To make the equations operational, it is necessary to specify the form of the production function. I employ a constant elasticity of substitution production function augmented by a term for the cost of adjustment.

23. Formulating the production function with costs of adjustment comes out of long tradition. See Robert E. Lucas, Jr., "Optimal Investment Policy and the Flexible Accelerator," International Economic Review, vol. 8 (February 1967), pp. 78-85; and Lucas and Prescott, "Investment Under Uncertainty." Adjustment costs are used to derive $q$-theoretic models of investment in Abel, Investment and the Value of Capital; Summers, "Taxation and Corporate Investment"; and Hayashi, "Tobin's Marginal $q$ and Average q." 
The production function is

(4) $f\left(K_{t-1}, I_{t}, L_{t}, \epsilon_{t}\right)=\alpha_{0}\left[\alpha K_{t-1}^{\mathrm{\rho}}+(1-\alpha) L_{t}^{\mathrm{\rho}}\right]^{1 / \rho}\left[1-\left(\frac{g}{2}\right) \frac{I_{t}^{2}}{\delta K_{t-1}}\right] \epsilon_{t}$, where $\alpha_{0}, \alpha, \rho$, and $g$ are parameters of the production function. The parameter $\delta$ is the depreciation rate of the capital stock. The $\alpha$ is the standard share parameter, and $\rho$ parameterizes the elasticity of substitution. When $\rho$ equals zero, the production function is Cobb-Douglas in the level variables $K$ and $L$. When $\rho$ is less than zero, it is constant elasticity of substitution, with elasticity of substitution of capital and labor less than the unit value of the Cobb-Douglas. The parameter $g$ governs the degree of the cost of adjustment. Investment enters the production function to capture the cost of adjusting the capital stock. It is scaled by the capital stock, so adjustment cost does not grow as a fraction of output as the economy grows. The productivity shocks are Hicks-neutral.

In order to derive a demand for capital, it is necessary to solve these first-order conditions. Moreover, even though the representative firm does not take into account the effect on other markets of its attempting to increase supply, the estimates of responses of capital to shocks should take it into account. The degree to which the capital stock will respond is constrained by the supply of other factors in the economy. In particular, the supply of labor must be taken into account. Assume that the supply of labor is inelastic. ${ }^{24}$ Specifically, labor supply follows the process

$$
L_{t}=\bar{L} v_{t},
$$

where $\bar{L}$ is the mean value of labor supply and $v_{t}$ is a labor supply shock.

Equation 5 has an alternative interpretation that does not require period-by-period clearing of a spot labor market. In Stanley Fischer's model of nominal contracting, firms precommit to a fixed nominal wage in a long-term contract. ${ }^{25}$ The labor shock, $v_{t}$, can then be interpreted as

24. This assumption is made in Summers, "Taxation and Corporate Investment." It is a simple way of imposing the constraint of the scale of the economy.

25. See Stanley Fischer, "Long-Term Contracts, Rational Expectations, and the Optimal Money Supply Rule," Journal of Political Economy, vol. 85 (February 1977), pp. 191-205; and Fischer, "Anticipations and the Nonneutrality of Money," Journal of Political Economy, vol. 87 (April 1979), pp. 225-52. See also John B. Taylor, "Aggregate Dynamics and Staggered Contracts," Journal of Political Economy, vol. 88 (February 1980), pp. 1-23. These arrangements need not be legal contracts, but can also be informal 
the deviation of labor from the long-run equilibrium labor supply caused by surprises that occur after the contract is signed. Firms are always on their demand for labor function, but workers need not be on their labor supply functions. The rigidity of wages gives scope for aggregate demand variables to affect output. Fischer's model may be regarded as a formalization of Keynes's discussion of sticky wages. ${ }^{26}$

Of course, the shock $v_{t}$ could be a mixture of neoclassical labor supply shocks and labor surprises arising because of nominal contracts. Because the implications of the model for output and investment are consistent with these two broadly different views of the labor market, it is probably best to regard this analysis as partial equilibrium.

The productivity shock, $\epsilon_{t}$, and the labor shock, $v_{t}$, have a measured correlation as high as one-third. This correlation does not complicate the calculation of the implications of the model, but it does call for some explanation. If there are short-run increasing returns to labor, labor shocks are partially causing the productivity shocks. The implications of this causation are discussed below.

I assume that the supply of capital goods and the supply of saving are perfectly elastic.

Given the parameterized production function in equation 4 , the nonlinear stochastic first-order conditions in equations 2 and 3 can be estimated directly by nonlinear instrumental variables procedures. ${ }^{27} \mathrm{In}$ this paper, I use estimates from my previous research. Moreover, I seek a closed-form solution that yields predictions that can be related easily to the actual data. Hence, I linearize the model. ${ }^{28}$ It is important to

long-term agreements. See Arthur M. Okun, Prices and Quantities: A Macroeconomic Analysis (Brookings, 1981).

26. Fischer's model shares with Keynes's the counterfactual prediction of countercyclic real wages. Productivity shocks may provide a reconciliation of these models with the facts. Neither model assumes sticky prices, so firms are unconstrained in how much they can sell. It is hard to believe that sales constraints arising from price stickiness could be very important for the firm's investment decision. It is unrealistic to believe that firms can adjust their capital stock faster than they can adjust their prices.

27. I consider this problem in detail in Shapiro, "The Dynamic Demand for Capital and Labor"'; and Shapiro, "Capital Utilization and Capital Accumulation: Theory and Evidence," Journal of Applied Econometrics, forthcoming.

28. See Andrew B. Abel and Olivier J. Blanchard, "The Present Value of Profits and Cyclical Movements in Investment," Econometrica, vol. 54 (March 1986), pp. 249-73; and Ben S. Bernanke, "The Determinants of Investment: Another Look," American Economic Review, vol. 73 (May 1983, Papers and Proceedings, 1982), pp. 71-75, for 
specify the model first in nonlinear form and then to linearize so that the coefficients in the linearized equations will impose approximately the restriction implied by the theory. For example, the same underlying parameters govern both the level of output (in the output equation) and the marginal product of capital (in the investment equation).

Maximizing equation 1 with respect to capital and labor to yield equations 2 and 3, linearizing the first-order conditions together with equation 5 , substituting equation 5 into equations 2 and 3 , and solving for capital yields the linearized demand for capital,

$$
K_{t}=\lambda_{0} K_{t-1}+\sum_{i=0}^{\infty} \lambda_{1}^{i} E_{t} Z_{t+i} \gamma,
$$

where $Z_{t}=\left[p_{t}, p_{t+1}, R_{t}, \epsilon_{t}, \epsilon_{t+1}, v_{t}, v_{t+1}\right]$ is the vector of forcing variables. The $\lambda s$ and $\gamma$, a vector of parameters, are nonlinear functions of the production function, labor, and depreciation parameters. ${ }^{29}$ The equation states that the capital stock is a function of the lagged capital stock and the value of current and expected future values of the forcing variables. The sum of the elements of $\gamma$ corresponding to $p_{t}$ and $p_{t+1}$ is negative, which implies that a permanent decrease in the after-tax purchase price of capital increases the capital stock. The element of $\gamma$ corresponding to $R_{t}$ is positive, so an increase in the discount rate (which corresponds to a decrease in investors' required rate of return) increases capital. Likewise, the sums of the coefficients corresponding to the productivity shocks, $\epsilon_{t}$, and the labor shocks, $v_{t}$, are positive, implying that permanent positive shocks increase capital.

The linearized equation for output is

$$
y_{t}=\alpha_{I} I_{t}+\alpha_{K} K_{t-1}+\alpha_{\epsilon} \epsilon_{t}+\alpha_{\nu} v_{t},
$$

where the $\alpha$ coefficients are parameters. Investment enters the output equation negatively because of the cost of adjustment; capital enters

linearized models for the capital to yield closed-form solutions. Richard Meese starts with a quadratic model, so his first-order conditions are linear. See Richard Meese, "Dynamic Factor Demand Schedules for Labor and Capital under Rational Expectations, ' Journal of Econometrics, vol. 14 (September 1980), pp. 141-58. I linearize around sample average values. One could linearize around trend values, but because I difference the variables, doing so would not differ substantially from my procedure.

29. See, for example, Thomas J. Sargent, Macroeconomic Theory (Academic Press, 1979), chapter 14. 
with a lag because of delivery lags. Output responds positively to labor or productivity shocks.

Finally, in order to relate the predictions of the theory to businesscycle data, equation 6 , the equation for the capital stock, is transformed into an equation for investment with the identity $K_{t}=(1-\delta) K_{t-1}+I_{t}$, where $K_{t}$ is the net capital stock, $\delta$ is the rate of depreciation, and $I_{t}$ is the level of gross investment. This transformation yields

$$
I_{t}=\lambda_{0} I_{t-1}+\sum_{i=0}^{\infty} \lambda_{1}^{i}\left[E_{t} Z_{t+i}-(1-\delta) E_{t-1} Z_{t+i-1}\right] \gamma
$$

Hence, investment depends on its lagged values plus expectations of forcing variables. Recall that the vector of forcing variables, $Z_{t}$, includes values of the productivity and labor shocks, which also enter the equation for output, equation 7 , and are hence the source of the positive correlation of investment and output. This positive correlation is partially offset by the negative contribution of investment to output because of the cost of adjustment embodied in the $\alpha_{I}$ term in the production function. ${ }^{30}$

To provide a solution for the variables of interest, it is necessary to take out the expected values of the forcing variables, $Z_{t}$. Suppose they follow the following processes:

$$
\begin{aligned}
R_{t} & =\sum_{i=0}^{\infty} \theta_{i}^{R} u_{t-i}^{R}, \\
p_{t} & =\sum_{i=0}^{\infty} \theta_{i}^{p} u_{t-i}^{p}, \\
\epsilon_{t} & =\sum_{i=0}^{\infty} \theta_{i}^{\epsilon} u_{t-i}^{\epsilon}, \\
v_{t} & =\sum_{i=0}^{\infty} \theta_{i}^{v} u_{t-i}^{v} .
\end{aligned}
$$

30. This partial, negative effect of investment on output is an important ingredient in my account of the cyclicality of productivity in the business cycle. In a real business-cycle model, labor productivity is procyclical because productivity is driving fluctuations in output. Close examination of the data (see Robert J. Gordon, "The 'End-of-Expansion' Phenomenon in Short-Run Productivity Behavior," BPEA, 2:1979, pp. 447-61, for example) reveals that measured labor productivity leads output in the business cycle. That is, labor productivity begins to decline before the peak of the cycle is reached. Costs of adjustment of capital might account for this end-of-expansion effect. During peak periods of investment, which coincide with peak periods of output, adjustment cost is highest. 
In these equations, the forcing variables are the functions of current and past values of shocks. These shocks are assumed to be unpredictable by other variables in the economy. In particular, they cannot be predicted by either output or investment. This condition holds in the context of the model for the productivity and labor shocks. It need not hold a priori for the purchase price and discount rate, yet it may be a feature of the model and of the data. For example, if the supply of saving and the supply of capital goods are elastic, then there will be no feedback from investment demand shocks to the forcing variables.

With equations 9 through 12 , one can calculate the expected future values of the forcing variables, $Z_{t}$, that enter equation 6 , the equation for capital. ${ }^{31}$ Thus, investment can be expressed solely as a function of current and lagged values of the shock, $u_{t}$, in the processes for $Z_{t}{ }^{32}$ Likewise, output can be expressed in terms of the shocks. Hence, output and investment follow the bivariate process

$$
\left[\begin{array}{l}
I_{t} \\
y_{t}
\end{array}\right]=\sum_{i=0}^{\infty} \psi_{i} u_{t-i},
$$

where the $\psi_{i}$ are coefficients of the shocks and $u_{t}$ is the vector of the innovations in equations 9 through 12 . Because the processes for forcing variables may have unit roots, so might the processes in equation 13 . To eliminate them, consider the processes for the changes in investment and output. They are

$$
\left[\begin{array}{l}
\Delta I_{t} \\
\Delta y_{t}
\end{array}\right]=\sum_{i=0}^{\infty} \phi_{i} u_{t-i},
$$

where again the $\phi_{i}$ are parameters. Given estimates of the variances and covariances of the innovations, it is straightforward to calculate the variance and covariances of the change in investment and in output from the moving average representation..$^{33}$ An aim of this study is to see whether they replicate those of the actual data.

31. See, for example, Lars Peter Hansen and Thomas J. Sargent, "Formulating and Estimating Dynamic Linear Rational Expectations Models," Journal of Economic Dynamics and Control, vol. 2 (February 1980), pp. 7-46.

32. Because of the autoregressive component in equation 6 this final form will have lags of $u_{t}$ into the infinite past. Alternatively, capital can be expressed as an ARIMA process with finite order moving average and autoregressive components.

33. Throughout the paper, I suppress calculation and discussion of the constants in the equations. Because the series contain unit roots, these constants determine the drift 


\section{Empirical Dynamics of Investment, Output, and the Cost of Capital}

In this section, I explore the facts that serve as the motivation for this study. I seek to demonstrate the strong correlation of output and investment and to study the extent to which, given output, the cost of capital affects investment. The data used in this section describe the aggregate U.S. private economy for the period 1955 through 1985:3. The technique, in addition to presenting simple, descriptive statistics, is to estimate fairly unrestricted reduced forms of the model. Although the mechanics of my procedures are similar to those of vector autoregressive studies, the similarity of my procedure with those is limited. ${ }^{34}$ Specifically, I will impose restrictions on the equations. First, only variables motivated by the theoretical model will enter the equations. Second, when lagged values of variables appear to have zero coefficients, they will be excluded from the equations.

\section{SIMPLE CORRELATIONS}

The data are described in detail in the appendix. In short, they are gross domestic product of private business, $y_{t}$; gross private fixed investment, $I_{t}$; the required rate of return on corporate capital expressed as a discount rate, $R_{t}$; the real after-tax purchase price of new investment goods, $p_{t}$; and the man-hours of employees in private business, $L_{t}$. The flow variables are expressed at quarterly rates, so profits in equation 1 are quarterly. The data from the national income and product accounts reflect the major revisions published in December 1985. These revisions included definitional changes, new benchmarks to reflect recent economic censuses, and rebasing of the price indexes to 1982. Use of the revised data is particularly important in this study because one of the

of the series. For example, the change in the productivity shock will have a positive constant if there is some certain increment to productivity each period. Likewise, there may be a deterministic component to the change in labor supply. (Note that even if this is the case, it is still inappropriate to detrend the series using a linear time trend.) These drift terms will induce drift in output and capital.

34. See Christopher A. Sims, "Macroeconomics and Reality," Econometrica, vol. 48 (January 1980), pp. 1-48; and Sims, "Policy Analysis with Econometric Models," BPEA, 1:1982, pp. 107-52. 
Table 1. Correlation Matrix and Standard Deviations of the Data, 1955:1-1985:3

\begin{tabular}{|c|c|c|c|c|c|c|c|}
\hline Item & $\begin{array}{c}\text { Invest- } \\
\text { ment }\end{array}$ & Output & $\begin{array}{l}\text { Price of } \\
\text { capital }\end{array}$ & $\begin{array}{l}\text { Discount } \\
\text { rate }\end{array}$ & Labor & $\begin{array}{c}\text { Produc- } \\
\text { tivity } \\
\text { shock, } \\
\text { Cobb- } \\
\text { Douglas }^{\mathrm{b}}\end{array}$ & $\begin{array}{l}\text { Produc- } \\
\text { tivity } \\
\text { shock, } \\
C E S^{c}\end{array}$ \\
\hline Investment & 1.0 & & & & & & \\
\hline Output & 0.61 & 1.0 & & & & & \\
\hline Price of capital & 0.07 & -0.02 & 1.0 & & & & \\
\hline Discount rate & -0.01 & -0.03 & 0.13 & 1.0 & & & \\
\hline Labor & 0.70 & 0.73 & 0.17 & 0.10 & 1.0 & & \\
\hline $\begin{array}{l}\text { Productivity shock, } \\
\text { Cobb-Douglas }\end{array}$ & 0.42 & 0.87 & -0.15 & -0.13 & 0.32 & 1.0 & \\
\hline $\begin{array}{l}\text { Productivity shock, } \\
\text { CES }\end{array}$ & 0.33 & 0.79 & -0.19 & -0.15 & 0.16 & 0.98 & 1.0 \\
\hline Standard deviation & 2.0 & 6.6 & 0.014 & 0.006 & 0.80 & 0.010 & 0.009 \\
\hline $\begin{array}{l}\text { voemcient of } \\
\text { variation }\end{array}$ & 2.9 & 1.7 & $\ldots .^{d}$ & 0.006 & 3.1 & 2.3 & 2.0 \\
\hline
\end{tabular}

Source: Author's calculations. For definitions and sources of the data, see text and appendix.

a. All variables are expressed as first differences, except the discount rate. Productivity shocks are the residuals from equation 4.

b. $\rho$, which parameterizes the elasticity of substitution in equation 4 , equals zero.

c. Constant elasticity of substitution, where $\rho$ equals -0.4 in equation 4 .

d. Mean value approximately zero.

most important definitional changes occurred in the deflation of producers' durable equipment.

Table 1 gives the sample standard deviations and correlations of the variables. Preliminary analysis suggests that the variables, except for the ex post discount rate, $R_{t}$, are clearly nonstationary and hence are differenced. The bottom two rows of the table give the standard deviation of each variable and the ratio of the standard deviation to the mean. The well-known facts about the joint variability of fixed investment and output easily emerge from the table. Fixed investment is, relative to its mean, nearly twice as variable as is output. Moreover, the correlation between the change in investment and the change in output is very strong. On the other hand, the correlations of the change in investment with the change in the after-tax purchase price of capital and with the discount rate are small and statistically insignificant.

The business cycle is characterized not just by strong contemporaneous correlations of investment and output, but also by persistence of the correlations. Table 2 gives the first autocorrelations and cross- 
Table 2. Autocorrelations and Cross-Correlations at One Lag, 1955:1-1985:3 ${ }^{\text {a }}$

\begin{tabular}{|c|c|c|c|c|c|c|c|}
\hline Lagged variable & $\begin{array}{c}\text { Invest- } \\
\text { ment }\end{array}$ & Output & $\begin{array}{l}\text { Price of } \\
\text { capital }\end{array}$ & $\begin{array}{l}\text { Discount } \\
\text { rate }\end{array}$ & Labor & $\begin{array}{l}\text { Produc- } \\
\text { tivity } \\
\text { shock, } \\
\text { Cobb- } \\
\text { Douglas b }\end{array}$ & $\begin{array}{c}\text { Produc- } \\
\text { tivity } \\
\text { shock, } \\
C E S^{\mathrm{c}}\end{array}$ \\
\hline Investment & 0.49 & & & & & & \\
\hline Output & 0.52 & 0.28 & & & & & \\
\hline Price of capital & 0.03 & -0.16 & 0.14 & & & & \\
\hline Discount rate & -0.06 & -0.04 & 0.14 & 0.66 & & & \\
\hline Labor & 0.61 & 0.29 & 0.20 & 0.04 & 0.52 & & \\
\hline $\begin{array}{l}\text { Productivity shock, } \\
\text { Cobb-Douglas }\end{array}$ & 0.30 & 0.19 & -0.04 & -0.07 & 0.33 & 0.08 & \\
\hline $\begin{array}{l}\text { Productivity shock, } \\
\text { CES }\end{array}$ & 0.21 & 0.14 & -0.08 & -0.07 & 0.25 & 0.05 & -0.01 \\
\hline
\end{tabular}

Sources: Author's calculations. See text description.

a. All variables are expressed as first differences, except the discount rate. Productivity shocks are the residuals from equation 4 .

b. $\rho$, which parameterizes the elasticity of substitution in equation 4 , equals zero.

c. Constant elasticity of substitution, where $\rho$ equals -0.4 in equation 4 .

correlations of the data. Investment and output are positively autocorrelated, but not very strongly. A striking feature of table 2 is the strong cross-correlation between the change in investment and the change in output: the persistence of the cross-correlation is stronger than the persistence displayed in the autocorrelation of either series.

Despite the weak correlation of the changes in investment and the purchase price of capital contemporaneously and at one lag, the data do provide some evidence of longer run correlations. In particular, the correlation of the two series becomes as high as -0.30 at six lags.

\section{DYNAMICS}

To characterize the dynamics reflected in the data, I have estimated a moderately unrestricted reduced form corresponding to the model of investment dynamics discussed above. Specifically, I estimate the vector autoregressive system of the variables presented in table $1 .{ }^{35}$ The theory implies that the quantity of investment should be a function of current and lagged values of the forcing variables: the purchase price, the

35. Other variables could enter the autoregressions if they help to predict the forcing variables even if they are not causal. 
Table 3. Tests of Granger Causality for Unrestricted Vector Autoregressions, 1955:1$1985: 3^{a}$

Marginal significance for test that variable in row does not Granger cause variable in column $^{\text {b }}$

\begin{tabular}{lcccrc}
\hline \multicolumn{1}{c}{ Variable } & $\begin{array}{c}\text { Invest- } \\
\text { ment }\end{array}$ & Output & $\begin{array}{c}\text { Price of } \\
\text { capital }\end{array}$ & $\begin{array}{c}\text { Discount } \\
\text { rate }\end{array}$ & Labor \\
\hline Investment & 0.35 & 0.77 & 0.15 & $>0.99$ & 0.81 \\
Output & 0.05 & 0.35 & 0.10 & 0.88 & 0.40 \\
Price of capital & 0.36 & 0.04 & 0.15 & 0.04 & 0.01 \\
Discount rate & 0.59 & 0.90 & 0.28 & $<0.01$ & 0.38 \\
Labor & 0.02 & 0.10 & 0.43 & 0.68 & 0.07 \\
Allc & $<0.01$ & 0.03 & 0.07 & $<0.01$ & $<0.01$ \\
\hline
\end{tabular}

Source: Author's calculations. See text description.

a. All variables are expressed as first differences, except the discount rate. Each variable is regressed on the constant and two lagged values of all five variables.

b. The numbers in the table give the significance level at which one can reject the hypothesis that two lags of the item in the row are not useful, given the other variables, in forecasting the variable in the column.

c. Significance for the test that none of the lagged variables forecasts the variable in the column.

discount rate, and the supply shocks. The productivity and labor supply shocks are unobserved. Labor and output are allowed to enter the system; the productivity and labor shocks are important components of the disturbances in these equations. As a preliminary statistical test, I estimate unrestricted vector autoregressions for the five variables. Each variable is regressed on the constant and two lagged values of all of the five variables. Tests of Granger causality from this estimation are presented in table 3 . The numbers in table 3 give the significance level at which one can reject the hypothesis that the two lags of the variable in the row are not useful-given the other variables-in forecasting the variable in the column. The last row gives the significance level for the test of the hypothesis that none of the variables is useful in forecasting the variable in the column.

Labor and output are useful in forecasting investment; the discount rate and the after-tax purchase price of capital are not. On the other hand, the quantity variables do not Granger cause the discount rate and the purchase price. ${ }^{36}$ Hence, in the estimated autoregressions, there is no feedback from the quantities to the price variables, $p_{t}$ and $R_{t}$. Thus, the estimated autoregressions contain only variables suggested by the

36. Recall that this Granger noncausality of quantities by prices is used to solve for the capital equation. 
theory and have zero restrictions supported by the data and used in the model to derive the equations for investment and output.

The unrestricted equations, those for the change in investment, output, and labor, are estimated with two lagged values of each of the five variables. The restricted equations, those for the after-tax purchase price of capital and the discount rate, are estimated as first-order autoregressions; the hypothesis that the other variables enter cannot be rejected at conventional levels of significance. The estimated restricted autoregressions for the discount rate and the after-tax purchase price of capital are discussed below. ${ }^{37}$

Table 4 gives the variances and correlations of the residuals from these regressions. The equations account for about half the variance of the change in investment and only about 20 percent of the change in output. Note that the contemporaneous correlations of the residuals in the purchase price and discount rate equations with those in the investment, output, and labor equations are essentially zero. This analysis does not rely on the arbitrary orthogonalization of the covariance matrix for which policy analysis and model testing using vector autoregressions have been criticized. ${ }^{38}$ Yet, it provides a way to summarize the contemporaneous correlations of the data abstracting from the lags in the system.

\section{Does the Model Account for the Observed Data?}

A theory is required to unscramble the source of the shocks described in the previous section. In the first section of this paper, I describe how output shocks can be an important factor in determining both investment and output. Nonetheless, there remains an important role for the cost of capital in determining investment. In this section, I parameterize the model using values from previous estimation and estimates of processes for the forcing variables. I then calculate statistics implied by the model analogous to the ones calculated above for the actual data.

37. The estimation technique is seemingly unrelated regressions rather than least squares because different equations have different regressors.

38. See Thomas F. Cooley and Stephen F. LeRoy, "Atheoretical Macroeconomics: A Critique," Journal of Monetary Economics, vol. 16 (November 1985), pp. 283-308. 
Table 4. Correlation Matrix and Standard Deviations of the Estimated Residuals, 1955:1-1985: $3^{\mathrm{a}}$

\begin{tabular}{lccccc}
\hline \multicolumn{1}{c}{ Item } & $\begin{array}{c}\text { Invest } \\
\text { ment }\end{array}$ & Output & $\begin{array}{c}\text { Price of } \\
\text { capital }\end{array}$ & $\begin{array}{c}\text { Discount } \\
\text { rate }\end{array}$ & Labor \\
\hline Investment & 1.0 & & & & \\
Output & 0.58 & 1.0 & & & \\
Price of capital & -0.03 & -0.07 & 1.0 & & \\
Discount rate & 0.17 & 0.03 & 0.10 & 1.0 & \\
Labor & 0.57 & 0.69 & 0.11 & 0.22 & 1.0 \\
Standard deviation & 1.5 & 6.2 & 0.014 & 0.005 & 0.66 \\
\hline
\end{tabular}

Source: Author's calculations. See text description.

a. All variables are expressed as first differences, except the discount rate. Residuals are from restricted vector autoregressions. The equations for the change in investment, output, and labor contain two lagged values of each of the five variables. The equations for the after-tax purchase price of capital and the discount rate are estimated as first-order equations. See text.

\section{PARAMETERIZING THE MODEL}

The first step in studying the model is to estimate the parameters of the equations for investment and output. The parameters required are the $\alpha$ s in equation 7 and $\lambda_{0}, \lambda_{1}$, and the $\gamma s$ in equation 6 . These parameters arise from linearizing the production function and from linearizing and solving the first-order condition for capital as discussed above. They are determined by the production function parameters and by the average values for the variables around which the equation is linearized. This procedure allows the coefficients of equations for investment and output to obey the strong restrictions implied by the theory. But it also provides simple linear expressions, which can be compared with the unrestricted ones discussed above.

To calculate the model's implications, I select values for the parameters of the production function, equation 4 . I assume the capital share, $\alpha$, equals the standard value of 0.25 . I present calculations for two values of the parameter, $\rho$, one equal to zero (the Cobb-Douglas case) and the other equal to -0.4 (a constant elasticity of substitution case with less substitutability of capital and labor than the Cobb-Douglas case). For the less familiar parameter, $g$, I use a value of 0.025 , chosen to be consistent with my previous estimates of the cost of adjustment. ${ }^{39}$ This

39. See Shapiro, "The Dynamic Demand for Capital and Labor," for estimates of the production function parameters. There I estimate $\alpha$ to be close to 0.25 . (The estimates are based on manufacturing, so I am assuming the same production function applies to the 
value implies that 2.4 percent of value added is lost each quarter through costs of adjustment when gross investment is at its average value. The parameter $\alpha_{0}$ is set so that the average value of $f\left(K_{t-1}, I_{t}, L_{t}, \epsilon_{t}\right)$ equals average output.

Equation 2 is linearized using these parameter values and the mean values for the data given in table 5. Labor demand is substituted out of the linearized first-order condition by setting it equal to the linearized labor equation, equation 5 . That equation is solved in terms of future values of the forcing variables to yield equation $6 .{ }^{40}$ Likewise, the production function is linearized to obtain equation 7 .

Table 5 presents the values of the coefficients implied by the two parameterizations of the production function. It also gives the mean value of the data around which the functions are linearized. In the equation for output, investment enters negatively because of the cost of adjustment, and capital enters with a lag because of the delay between the time the investment decision is made and the time when capital becomes productive.

In the equation for capital, time $t$ and time $t+1$ values of the aftertax purchase price of capital and the shocks enter because of the durability of capital and the costs of adjustment. If shocks are permanent, the magnitude of the effect of a shock to one of the variables on the capital stock will be determined by the sum of the time $t$ and time $t+1$ coefficients. Investment is given by quasi-differencing the equation for capital.

aggregate private economy.) In that paper, the form of the production function is slightly different. Consequently, $g$ is chosen to mimic the dynamics found in that paper, which are governed by the cost of adjustment. (If adjustment is less costly, it takes place more rapidly.) The value of $g=0.025$ yields the identical forward root $\left(\lambda_{1}\right.$ in equation 6), as I report in Shapiro, "The Dynamic Demand for Capital and Labor," footnote 9. (The backward root $\lambda_{0}$ is larger in this paper than the value reported in my previous paper because here capital becomes productive with a lag.) The adjustment costs are much lower than those implied by estimates based on $q$ theory (see Summers, "Taxation and Corporate Investment").

40. Note that the first-order condition, equation 2, contains current, lagged, and lead values of the capital stock. Hence, once linearized, it can be expressed as

$$
\left(a_{0} B^{-1}+a_{1}+a_{2} B\right) E_{t} K_{t}=E_{t} Z_{t} \gamma
$$

where $B$ is the lag operator and $Z_{t}$ are the forcing variables. The quadratic in $B$ can be factored. Solving the stable root backwards and the unstable root forwards yields equation 6. See Sargent, Macroeconomic Theory. 
Table 5. Parameterized Capital and Output Equations

Cobb-Douglas case ${ }^{\text {a }}$

$$
\begin{aligned}
\text { (6') } \quad K_{t}= & .96 K_{t-1}+E_{t} \sum_{i=0}^{\infty} .92^{i}\left(-163 p_{t+i}+156 p_{t+i+1}\right. \\
& \left.+164 R_{t+i}-63 \epsilon_{t+i}+70 \epsilon_{t+i+1}-0.59 v_{t+i}+0.65 v_{t+i+1}\right) \\
\left(7^{\prime}\right) \quad y_{t}= & -.39 I_{t}+0.056 K_{t-1}+502 \epsilon_{t}+4.7 v_{t} \\
& \text { Constant elasticity of substitution case } \\
\left(6^{\prime \prime}\right) \quad K_{t}= & .98 K_{t-1}+E_{t} \sum_{i=0}^{\infty} .94\left(-165 p_{t+i}+158 p_{t+i+1}\right. \\
& \left.+160 R_{t+i}-64 \epsilon_{t+i}+65 \epsilon_{t+i+1}-0.73 v_{t+i}+0.75 v_{t+i+1}\right) \\
\text { (7") } \quad y_{t}= & -.39 I_{t}+0.018 K_{t-1}+502 \epsilon_{t}+5.8 v_{t}
\end{aligned}
$$

Addendum:

(8') $\quad I_{t}=K_{t}+.976 K_{t-1}$

Mean valies:

$I_{t}=\$ 66$ billion (1982 dollars), quarterly rate

$y_{t}=\$ 502$ billion (1982 dollars), quarterly rate

$K_{t}=\$ 2,238$ billion (1982 dollars)

$p_{t}=0.58$, index

$R_{t}=0.99$, discount factor, quarterly rate

$\epsilon_{t}=1$, by definition

$v_{t}=1$, by definition

Source: Author's estimates. See text description and equations 6,7 , and 8 .

a. $\rho$, which parameterizes the elasticity of substitution in equation 4 , equals zero.

b. $\rho$ equals -0.4 .

Note that aside from the uncertainty about the future forcing variables, capital is fully determined by the production function and conditions in the labor market. Investment follows from identity, linking it to current and lagged capital stocks. Analyses of capital formation that try to make investment the primitive concept are difficult to implement if firms do set marginal product of capital equal to its cost. Because the capital stock is large and costly to adjust, current investment will have no fixed relation to the marginal product of capital unless the lagged capital stock is taken into account. ${ }^{41}$

Hence, one outcome of parameterizing the model is the investment equations implied in table 5 . These equations overcome two difficulties in standard estimation of such equations. First, they are solidly based in the technology that drives the firm's long-run capital accumulation

41. See Summers, "Requiem for the Investment Equation," for a forceful statement of this point. 
decision. Second, they present valid estimates of the effect of the cost of capital on investment despite the serious simultaneity problem.

\section{FORCING VARIABLES}

To provide a solution for the variables of interest, it is necessary to substitute out the expected future values of the forcing variables, $Z_{t}$. Moreover, the processes followed by the unobserved supply shocks must be identified. The processes for the observed components of $Z_{t}$ are discussed above. I use univariate approximations of the processes for the forcing variables.

First, consider the process for the quarterly discount rate, $R_{t}$. Recall that $R_{t}=1 /\left(1+r_{t}\right)$, where $r_{t}$ is the real after-tax required rate of return of investors. The required rate of return is unobservable, but it has observable analogues. As a measure of the required rate of return, I use the ex post real after-tax yield on Treasury bills plus a risk premium. (See the appendix for details.) Since the nominal return is known in advance, the difference between the ex post and ex ante yields derives only from the difference between actual and expected inflation. I need to estimate the process for the ex ante discount rate. Observing the ex post value causes two complications. First, it makes ordinary least squares estimation inappropriate. Second, it complicates measuring the variance of the innovation in the process for the discount rate. The first problem is easily overcome using instrumental variables estimation. The ex post value differs from the ex ante by a serially uncorrelated forecast error, so variables known at the beginning of the period are valid instruments. Hence, I estimate the process for the discount rate, equation 9 , as a first-order autoregression of the ex post values, but estimation is carried out by two-stage least squares using the nominal discount rate and the lagged inflation rate (measured as the reciprocal of the gross rate of price change) as instruments. The estimated equation is

$$
\begin{aligned}
& R_{t}=0.95 R_{t-1}+u_{t}^{R} \\
& \quad(0.11) \\
& \text { Standard error }=0.005,
\end{aligned}
$$

where the standard error is in parentheses. The standard errors are, of course, computed using the actual ex post values, not the fitted values 
from the first stage.$^{42}$ In addition to the estimates of the autoregressive parameter, I need an estimate of the variance of the innovation in the ex ante discount rate. ${ }^{43}$

I also consider an estimate of the discount rate based on the return on long-term corporate bonds. The definition of the series is given in the appendix. If ex ante returns are equalized across assets, as implied by the expectations theory of the term structure, it will not matter how the discount rate is measured. Given that the theory does not hold, it is not obvious which is the correct measure of the discount rate ${ }^{44}$ Estimating the univariate process for the discount rate with the data on long rates yields

$$
\begin{gathered}
R_{t}=0.98 R_{t-1}+u_{t}^{R} \\
\quad(0.07) \\
\text { Standard error }=0.005 .
\end{gathered}
$$

The dynamics implied by equations $9^{\prime}$ and $9^{\prime \prime}$ are similar, so using either set of estimates would yield similar results.

To measure the discount rate, I use an interest rate plus constant equity premium, rather than the quarter-to-quarter return on equity. An alternative would be to use the equity returns themselves. The problem with using the returns is that although ex post there is huge variability in the returns, ex ante it is very hard to reject the hypothesis that the return is a constant.$^{45}$ If there is no ex ante variability of stock returns, stock market variability will account for no variability of investment. This does not imply that there is no correlation of investment with the level

42. If equation $9^{\prime}$ is estimated by ordinary least squares, the autoregressive coefficient is 0.66 with a small standard error.

43. Note that the standard error overstates the variance of the innovation because it includes the unpredictable variability of inflation. To correct for this, I use the estimated variance and autocorrelations of the residuals in the first-stage regression to impute the variance of the residuals in equation $9^{\prime}$. This calculation yields 0.001 as an estimate of the upper bound of the standard deviation of the innovation in the ex ante discount rate. This is the figure that will be used below in calculating the implications of the model.

44. For a rejection of the expectations theory of the term structure, see N. Gregory Mankiw, "The Term Structure of Interest Rates Revisited," in this volume.

45. See Robert C. Merton, "On Estimating the Expected Return on the Market: An Exploratory Investigation, ' Journal of Financial Economics, vol. 8 (December 1980), pp. 323-61. 
of the stock market. Both may increase in response to positive supply shocks. ${ }^{46}$

Now consider the process for the real after-tax purchase price of capital. The hypothesis that $p_{t}$ follows a random walk cannot be rejected at the 5 percent level even using conventional critical values (see table 3 ). It is constrained by the following random walk:

$$
\begin{gathered}
p_{t}=p_{t-1}+u_{t}^{p} \\
\text { Standard error }=0.014 .
\end{gathered}
$$

Consequently, changes in the purchase price are expected to be permanent. Tax changes provide the major source of variation in the purchase price of capital. Although a reasonable working assumption would be that changes in tax laws are permanent, there are times when such an assumption is inadequate. For example, in 1969 the investment tax credit was temporarily allowed to lapse. Businessmen may have regarded the change as temporary. Currently, Congress is debating tax reform proposals that include repeal of the investment tax credit and curtailment of accelerated depreciation allowances. Given these debates, it would be unreasonable to assume that the current 10 percent investment tax credit is permanent. Nevertheless, expecting tax changes to be permanent is likely to be a good assumption when further changes are not being debated, and it is certainly what the statistical analysis implies.

Now consider the process for the productivity shock, $\epsilon_{t}$, and the labor shock, $v_{t}$. Although these shocks are unobserved disturbances in the production function, equation 4 , and the labor equation, equation 5 , their properties can be estimated. My procedure is to calculate the residuals from equations 4 and 5 using the data discussed above. ${ }^{47}$ Note that the productivity shock is calculated net of the labor shock. I then study the properties of the residuals in order to identify stochastic processes for the respective shocks. The standard deviations, correla-

46. Blanchard and Summers find that profitability shocks are an important element in explaining the combination of high real interest rates and high stock prices. See Blanchard and Summers, "Perspectives on High World Interest Rates." The productivity shocks highlighted here are one example of such changes in profitability.

47. Prescott calculates productivity shocks as residuals in a production function, but he uses a complicated detrending procedure rather than differencing to render them stationary. See Prescott, "Theory Ahead of Business Cycle Measurement." 
tions, and autocorrelations of the change in the productivity shocks are given in tables 1 and 2. Calculations for both the Cobb-Douglas and constant elasticity of substitution (CES) with $\rho=-0.4$ cases are presented. Note that under the assumption of inelastic labor supply or Fischer's contracts, $\Delta L_{t}$ and $\Delta v_{t}$ will have identical standard deviations and correlations. The standard deviations of the shocks are large, about 1 percent per quarter. The correlations with the change in output and the change in investment of the changes in the productivity shocks are high and moderately persistent.

Leaving aside the terms in $K$ and $I$, the calculation of $\nu_{t}$ and $\epsilon_{t}$ is simply a decomposition of the changes in output into changes directly attributable to changes in labor and a residual. Attributing all changes in $\epsilon_{t}$ to supply shocks would be misleading if there were short-run increasing returns to labor. I discuss the quantitative importance of this issue below.

To identify the stochastic processes followed by the shocks, I calculate their autocorrelations and partial autocorrelations. The processes clearly have unit roots, so they are differenced. The observed processes for output and investment have unit roots. ${ }^{48}$ This could be generated by unit roots in the forcing variables.

Table 6 gives the autocorrelations and partial autocorrelations of the productivity shocks. At all lags, the correlations are very weak. At a few of the lags, they are significant, but they are never above 0.25 in absolute value and are insignificant at the first lags for both the autocorrelations and partial autocorrelations. These findings are consistent with the productivity shocks being approximately white noise in differences. These findings are also confirmed by estimating autoregressive and moving-average models for the shocks. For both the Cobb-Douglas case and the CES case, first-order autoregressive and moving-average coefficients in regressions of the change in $\epsilon$ are very small and statistically insignificant. The presence of a unit root in the moving-average representation of $\Delta \epsilon$ would indicate that taking differences of $\epsilon$ is in fact overdifferencing and that the nonstationarity of $\epsilon$ comes from a trend component. There is, however, no evidence of a moving-average unit root. Consequently, the process for the supply shock is constrained to be a random walk. That is,

48. See Nelson and Plosser, "'Trends and Random Walks, " and Campbell and Mankiw, "Are Output Fluctuations Transitory?" 
Table 6. Autocorrelations and Partial Autocorrelations of Shocks, 1955:1-1985:3a

\begin{tabular}{|c|c|c|c|c|c|c|}
\hline \multirow[b]{2}{*}{ Lag } & \multicolumn{2}{|c|}{$\begin{array}{l}\text { Productivity shock, } \\
\text { Cobb-Douglas }\end{array}$} & \multicolumn{2}{|c|}{$\begin{array}{l}\text { Productivity shock, } \\
C E S^{\mathrm{c}}\end{array}$} & \multicolumn{2}{|c|}{ Labor shock } \\
\hline & $\begin{array}{l}\text { Auto- } \\
\text { correlation }\end{array}$ & $\begin{array}{c}\text { Partial } \\
\text { auto- } \\
\text { correlation }\end{array}$ & $\begin{array}{l}\text { Auto- } \\
\text { correlation }\end{array}$ & $\begin{array}{c}\text { Partial } \\
\text { auto- } \\
\text { correlation }\end{array}$ & $\begin{array}{l}\text { Auto- } \\
\text { correlation }\end{array}$ & $\begin{array}{c}\text { Partial } \\
\text { auto- } \\
\text { correlation }\end{array}$ \\
\hline 1 & 0.09 & 0.09 & 0.00 & 0.00 & $0.52^{*}$ & $0.52 *$ \\
\hline 2 & $0.23^{*}$ & $0.23^{*}$ & $0.21^{*}$ & $0.21^{*}$ & $0.24^{*}$ & -0.05 \\
\hline 3 & -0.08 & -0.12 & -0.14 & -0.14 & 0.06 & 0.05 \\
\hline 4 & 0.02 & -0.02 & 0.00 & -0.04 & -0.02 & 0.04 \\
\hline 5 & -0.09 & -0.05 & -0.08 & -0.03 & -0.06 & -0.03 \\
\hline 6 & -0.01 & -0.02 & 0.01 & 0.00 & -0.09 & -0.05 \\
\hline
\end{tabular}

Source: Author's calculations. See text description. Asterisk indicates that correlation is significant at the 0.05 level using a two-tailed $t$ test.

a. Productivity shocks and the labor shock are the residuals from equations 4 and 5 , respectively. Data are in first differences.

b. $\rho$, which parameterizes the elasticity of substitution in equation 4 , equals zero.

c. Constant elasticity of substitution, where $\rho$ equals -0.4 in equation 4 .

d. Labor shock is change in measured man-hours.

$$
\epsilon_{t}=\epsilon_{t-1}+u_{t}^{\epsilon} .
$$

The standard errors of the innovations for the Cobb-Douglas and CES cases are 0.010 and 0.009 , respectively.

Table 6 also gives the autocorrelations and the partial autocorrelations for the changes in the labor shock. The autocorrelations die out smoothly; only the first partial autocorrelation is significantly nonzero. This pattern implies that the changes in the shocks follow a first-order autoregressive process. ${ }^{49}$ Recall that changes in investment and output do not Granger cause changes in labor (table 3 ). The estimated process is

$$
v_{t}=v_{t-1}+0.53\left(v_{t-1}-v_{t-2}\right)+u_{t}^{v}
$$

$$
\text { Standard error }=0.68 \text {. }
$$

Equations $9^{\prime}$ through $12^{\prime}$ imply expected future values for the forcing variables as functions of current and lagged values of the innovations, $u_{t}$. To eliminate the expected future values of the forcing variables from equation 6 , their expectations are calculated using equations $9^{\prime}$ through $12^{\prime}$. Substituting out these expectations and substituting capital and

49. The model that Fischer presents implies that equation 12' should be a finite-order moving average. See Fischer, "Long-Term Contracts." Taylor's model in "Aggregate Dynamics" could be consistent with equation 12 ' being autoregressive. 
investment out of the equation for output yields equation 13. Because the processes for the forcing variable have unit roots, so will equation 13; they are differenced to yield equation 14 .

\section{IMPLIED STANDARD DEVIATIONS AND CORRELATIONS}

From equation 14, it is straightforward to calculate the variances and correlations of the output and investment that are reported in the tables. These are functions for the parameters of the capital and output equations given in table 5, the parameters of the stochastic processes for the forcing variables given in equations $9^{\prime}$ through $12^{\prime}$, and the variances of the innovations in those equations.

Table 7 gives the standard deviations and correlations of the change in investment and output that are implied by the model for the two assumptions about the elasticity of substitution. The standard deviations of both the change in output and the change in investment are close to those reported in table 1 for the actual data. The contemporaneous correlation of the changes is high and close to that in the actual data. Moreover, the model also generates the persistent correlations and cross-correlations of the actual data, although the correlation between the change in investment and the change in output at one lag is weaker than it was in the actual data.

Table 7 also gives the correlations implied by the model for the change in output and change in investment with the forcing variables. The correlation of the change in the after-tax purchase price of capital with the change in investment is -0.32 in the Cobb-Douglas case and -0.46 in the CES $(\rho=-0.4)$ case. This sign is consistent with theory. The correlation reported in table 1 for the actual data is small and positive, but, as noted above, it becomes as high as -0.30 at six lags. Hence, the model better mimicks the magnitude than the timing of the correlation of investment with the price.

The model does generate the lack of correlation of investment and the required rate of return found in the data. In both the actual data in table 1 and the model's results in table 7, the correlation of the changes in investment or output with the discount rate is virtually nil. This outcome is, perhaps, surprising because the neoclassical theory upon which the model is based has an effect for the required rate of return built into it. There are several reasons for the weak correlation of investment with 
Table 7. Correlations and Standard Deviations Implied by the Model ${ }^{\mathrm{a}}$

\begin{tabular}{|c|c|c|c|c|}
\hline \multirow[b]{2}{*}{ Item } & \multicolumn{2}{|c|}{ Cobb-Douglas ${ }^{\mathrm{b}}$} & \multicolumn{2}{|c|}{$\begin{array}{c}\text { Constant elasticity of } \\
\text { substitution }^{\mathrm{c}}\end{array}$} \\
\hline & Investment & Output & Investment & Output \\
\hline Investment & 1.0 & & 1.0 & \\
\hline Output & 0.53 & 1.0 & 0.17 & 1.0 \\
\hline Price of capital & -0.32 & 0.04 & -0.46 & 0.05 \\
\hline Discount rate & 0.02 & 0.00 & 0.04 & 0.00 \\
\hline Productivity shock & 0.39 & 0.70 & 0.04 & 0.68 \\
\hline Labor shock & 0.40 & 0.36 & 0.36 & 0.40 \\
\hline Investment, lagged & 0.01 & $\ldots$ & 0.01 & $\ldots$ \\
\hline Output, lagged & 0.16 & 0.39 & 0.13 & 0.43 \\
\hline Standard deviation & 2.3 & 6.8 & 1.9 & 7.4 \\
\hline
\end{tabular}

Source: Author's calculations, based on equations $9^{\prime}$ through $12^{\prime}$ in text.

a. All variables are expressed as first differences, except the discount rate.

b. $\rho$, which parameterizes the elasticity of substitution in equation 4 , equals zero.

c. Constant elasticity of substitution, where $\rho$ equals -0.4 in equation 4 .

the required rate of return. First, the variation in investment due to the supply shocks overwhelms the variation due to the rate-of-return shocks. Rate-of-return shocks contribute only a small fraction of the variance of investment. Second, shocks to the required rate of return are not permanent. Recall that the discount rate has an autoregressive coefficient of 0.95 , while all the other forcing variables have unit roots. Even with modest adjustment costs it is not profit-maximizing for firms to undertake large responses to transitory shocks. Note that the observation about the transitory nature of the shocks is subsidiary to the one about their small variance. Even if it were permanent, the response to a small shock would be small. Consequently, the correlation of investment and rateof-return shocks is small. Third, even if the unconditional correlation of investment and the required rate of return were small, the two could be correlated at particular frequencies. Finally, the estimated movements of the required rate of return are based on general equilibrium outcomes that are not fully modeled here. Hence, the calculations presented here summarize the model's implications given historical patterns, but they do not carry implications for a hypothesized independent change in the required rate of return.

Table 7 also reports the correlations of the changes in investment and output with the unobserved productivity and labor shocks. These correlations are high, but not as high as the correlation of the changes in 
investment and output with each other. They also match well the estimated correlations reported in table 1 for the historical data.

Overall, the correlations in the data and in the model are strikingly similar, except for the model's overprediction of the correlation of investment and the purchase price of capital. The model accurately captures the lack of correlation of investment and output with the required rate of return. Note that the assumption of elastic supply of savings provides for the largest response of investment to rate-of-return shocks. The correlation would be even smaller if savings supply were inelastic.

The actual data, of course, do not provide a direct estimate of the correlation of investment and output forecast errors with the forecast errors in the supply shocks. Yet it is interesting to note that the correlation of the unobserved productivity and labor supply shocks with investment and output in the model closely matches the correlation of the innovation in labor with investment and output and the correlation of the innovations of output and investment in the actual data.

\section{DECOMPOSING THE OUTPUT SHOCKS}

Some of the calculations above rely on decomposing changes in output into changes explained by changes in the inputs and those explained by changes in productivity. The changes in productivity are measured as residuals from a production function. In the presence of short-run increasing returns to labor (SRIRL), this method of calculating the productivity shock may be misleading. If a labor shock increases productivity in the short run, the estimated residuals from a production function overstate the contribution of pure productivity shocks to output. In this section, I examine the implications of SRIRL for the calculations in this paper.

Short-run increasing returns to labor may arise for a variety of reasons. ${ }^{50}$ Cost of adjustment of labor, labor hoarding, and low ex post substitutability between labor and capital all would cause changes in

50. See Arthur M. Okun, "Potential GNP: Its Measurement and Significance," in American Statistical Association, Proceedings of the Business and Economic Statistics Section (Washington, D.C.: ASA, 1962), pp. 98-104, for the seminal work on Okun's law. C. J. Morrison and E. R. Berndt provide a recent survey of this large literature and some new estimates of SRIRL. See Morrison and Berndt, "Short-Run Labor Productivity in a Dynamic Model," Journal of Econometrics, vol. 16 (August 1981), pp. 339-65. 
measured labor to change measured productivity. The estimated $\epsilon_{t}$ may include a component attributable to labor. Consequently, it is incorrect to conclude that the strong correlation of changes in output and $\epsilon_{t}$ described above necessarily implies that the changes in $\epsilon_{t}$ account for a given fraction of the variance in output.

It would be possible to incorporate SRIRL into the analysis by, for example, adding cost of adjustment for labor terms to the production function. ${ }^{51}$ Doing so would complicate the analysis yet would be unlikely to be empirically important for the demand for capital equation. Cost of adjustment for labor will enter the linearized demand for capital equation only if the costs of adjustment of capital and labor are interrelated. The production function estimates on which the parameterization in this paper are based have no important interrelated adjustment costs. ${ }^{52}$ Consequently, excluding this source of SRIRL from the specification of the production function in this paper does not contaminate the parameterized demand for capital equation.

Nonetheless, the SRIRL will affect calculations based on the production function itself, such as the estimates of the productivity shocks, $\epsilon_{t}$. To quantify its importance I consider the correlations of changes of the measured productivity shock, $\epsilon_{t}$, and the measured labor shock, $v_{t}$. By assuming that all correlations of changes of $\epsilon_{t}$ and $\nu_{t}$ are caused by the labor shock, I can provide an upper bound on the importance of SRIRL in the movements in output. ${ }^{53}$ The correlation between the changes is estimated to be 0.32 in the Cobb-Douglas case and 0.16 in the CES $(\rho=-0.4)$ case.${ }^{54}$ Hence, SRIRL is less important in the latter case.

51. Adding quadratic terms in labor to the production function can approximate sources of SRIRL in addition to internal adjustment cost. See also Morrison and Berndt, "Short-Run Labor Productivity."

52. I find no evidence of cost of adjustment for production workers, but large and statistically significant adjustment costs for nonproduction workers. See Shapiro, "Dynamic Demand." Christopher A. Sims finds no SRIRL for production workers. See Sims, "Output and Labor Input in Manufacturing," BPEA, 3:1974, pp. 695-728. Morrison and Berndt find that the SRIRL found in total labor is all due to nonproduction workers. See Morrison and Berndt, "Short-Run Labor Productivity." I find no significant interrelated adjustment cost between capital and nonproduction workers. (I find small but statistically significant interrelated adjustment costs between capital and production workers, but these are difficult to interpret in light of the absence of own-adjustment costs for production workers.)

53. This procedure is equivalent to the cyclical adjustment of productivity by regressing measured productivity on cyclical indicators, which here is labor.

54. See table 1. 
To quantify the potential importance of SRIRL, consider the effect of attributing all the correlations in $\epsilon_{t}$ and $\nu_{t}$ to $\nu_{t}{ }^{55}$ This attribution will affect the decomposition of variance, but not the estimate of total variance and covariance. Specifically, the calculations presented in table 7 are invariant to how one attributes the causality underlying the correlation of the shocks. Yet, this exercise is useful in interpreting the parameterized model. In the Cobb-Douglas specification, 49 percent of the variance of the change in output is accounted for by the variance of productivity changes, 36 percent is accounted for by the variance of labor changes, 14 percent is accounted for by the covariance of productivity and labor changes, and 1 percent is accounted for by changes in the components of the cost of capital. Hence, SRIRL is an important source of output variation. Incorrectly attributing that source of variation to independent productivity shocks could overstate their importance in accounting for the variation in output changes by as much as one-quarter.

The calculations presented in table 5 and table 7 are independent of this attribution. The parameters in table 5 follow directly from the specification of the technology. The standard deviations and correlations in table 7 are those one would calculate in an economy in which the data were generated by the equations in table 5 and by equations $9^{\prime}$ through $12^{\prime}$ in the text. As a logical extension of the decomposition of variance discussed above, one might wish to calculate the correlations based on productivity shocks purged of the part explained by labor. To do so, I regress the measured changes in $\epsilon_{t}$ on a constant and the measured change in labor. The residual, $\epsilon_{t}^{*}$, is an estimate of the cyclically adjusted productivity. ${ }^{56}$

55. This procedure is analogous to deciding the order of the orthogonalization of the covariance for innovation accounting with vector autoregressions.

56. The estimated equations are

$$
\begin{gathered}
\Delta \epsilon_{t}^{C D}=1.8+1.8 \Delta \nu_{t}+\Delta \epsilon_{t}^{C D *} \\
(1.8) \quad(5.4) \\
\text { Standard error }=0.0095
\end{gathered}
$$

and

$$
\begin{gathered}
\Delta \epsilon_{t}^{C E S}=2.1+1.1 \Delta \nu_{t}+\Delta \epsilon_{t}^{C E S *} \\
(1.4)(5.4) \\
\text { Standard error }=0.0093 .
\end{gathered}
$$

The estimation is carried out by two-stage least squares (2SLS) with the constant, real military expenditures, and military employment as instruments. The standard errors (in 
Table 8. Correlations and Standard Deviations of Investment, Output, and Orthogonalized Shocks: Actual Data and Implied by Model ${ }^{a}$

\begin{tabular}{|c|c|c|c|c|c|c|}
\hline \multirow[b]{3}{*}{ Item } & \multirow{2}{*}{\multicolumn{2}{|c|}{ Data $^{\text {b }}$}} & \multicolumn{4}{|c|}{ Implied by model } \\
\hline & & & \multicolumn{2}{|c|}{ Cobb-Douglas ${ }^{\mathrm{c}}$} & \multicolumn{2}{|c|}{$\begin{array}{c}\text { Constant elasticity of } \\
\text { substitution }^{\mathrm{d}}\end{array}$} \\
\hline & Investment & Output & Investment & Output & Investment & Output \\
\hline Output & 0.61 & 1.0 & 0.43 & 1.0 & 0.18 & 1.0 \\
\hline $\begin{array}{l}\text { Productivity shock, } \\
\text { Cobb-Douglas }\end{array}$ & 0.24 & 0.70 & 0.35 & 0.62 & & \\
\hline $\begin{array}{l}\text { Productivity shock, } \\
\text { CES }\end{array}$ & 0.20 & 0.65 & & & 0.04 & 0.61 \\
\hline Labor shock & 0.70 & 0.73 & 0.53 & 0.47 & 0.41 & 0.46 \\
\hline Standard deviation & 2.0 & 6.6 & 2.4 & 7.3 & 2.0 & 7.6 \\
\hline
\end{tabular}

Source: Author's calculations. See text description.

a. Data are in first differences. Orthogonalized shocks are computed as follows: the part of the productivity shock, $\epsilon_{t}$, contemporaneously correlated with the labor shock is subtracted from the productivity shock and is added to the labor shock.

b. See text and appendix for description.

c. $\rho$, which parameterizes the elasticity of substitution in equation 4 , equals zero.

d. Constant elasticity of substitution, where $\rho$ equals -0.4 in equation 4 .

Table 8 reports standard deviations and correlations of the changes in investment, output, and the shocks for the data and the two cases of the model. The calculations are based on the orthogonalized shocks; that is, the part of the $\epsilon_{t}$ shock contemporaneously correlated with the labor shock is subtracted from the productivity shock and is added, appropriately scaled, to the labor shock. The left-hand panel is analogous to table 1 and the center and right-hand panels are analogous to table 7. The earlier tables are based on the nonorthogonalized shocks.

Given the attribution to labor of part of the measured productivity shock, the correlations of the changes in productivity with changes in output and investment fall. For the Cobb-Douglas case, its correlation is 0.24 with investment changes and 0.70 with output changes in the data, compared with values of 0.42 and 0.87 for the nonorthogonalized shocks (table 1). In the Cobb-Douglas case of the model, the correlations

parentheses) are large. The analogous ordinary least squares (OLS) estimates are significant at conventional levels; the OLS point estimates of the slope parameters are only about 10 percent larger than the 2SLS ones. Lagged labor changes do not enter the regressions significantly. The autocorrelations of the residual productivity shocks are very similar to the autocorrelations for the raw shocks, so the productivity shocks are treated as in equation $11^{\prime}$, but with the standard errors from the above regressions. 
of changes in investment and output with the orthogonalized productivity shocks are 0.35 and 0.62 (table 8). These compare with values of 0.39 and 0.70 for the nonorthogonalized shocks (table 7). Hence, taking into account the possibility of SRIRL does reduce the correlation of the productivity shock with investment and output both in the data and in the model. Nonetheless, the orthogonalized productivity shock remains importantly correlated with changes in both investment and output. Analogous results hold for the CES case in which the elasticity of substitution is less than unity $(\rho=-0.4)$, although, not surprisingly, SRIRL is much less important in the lower elasticity of substitution case.

\section{What Remains for the Cost of Capital?}

In this section I explore the implications of the parameterized model for changes in the components of the cost of capital.

\section{PURCHASE PRICE}

During the 1980s, one important focus of government policy has been the after-tax purchase price of capital. The Economic Recovery Tax Act of 1981 substantially reduced the price by increasing the investment tax credit and accelerating depreciation allowances. Current proposals to change the tax code would increase the price of capital by repealing the investment tax credit and curtailing the acceleration of depreciation allowances. That changes in output seem to account for much of the variance in changes in investment can be interpreted as evidence that such tax incentives have little or no effect. ${ }^{57} \mathrm{My}$ model, however, predicts that the effect of changing the after-tax purchase price of capital can be significant.

Table 9 presents the response of the level of investment and the capital stock to a permanent decrease in the after-tax purchase price of capital, $p_{t}$. The decrease in the price is 2.4 percent, which equals one standard deviation of the innovation in the estimated process, equation $10^{\prime}$. The first two columns give the response of investment and capital as predicted 
Table 9. Predicted Response of Investment and Capital to Shocks

Billions of 1982 dollars

\begin{tabular}{|c|c|c|c|c|c|c|}
\hline \multirow[b]{3}{*}{ Quarter } & \multicolumn{4}{|c|}{2.4 percent decrease in price of capital ${ }^{\mathrm{a}}$} & \multirow{2}{*}{\multicolumn{2}{|c|}{$\begin{array}{l}40 \text { basis point decline } \\
\text { in interest rate, } \\
\text { Cobb-Douglas }\end{array}$}} \\
\hline & \multicolumn{2}{|c|}{ Vector autoregression ${ }^{\mathrm{b}}$} & \multicolumn{2}{|c|}{ Cobb-Douglas } & & \\
\hline & Investment & Capital & Investment & Capital & Investment & Capital \\
\hline 1 & 0.05 & 0.00 & 0.71 & 0.00 & 1.26 & 0.00 \\
\hline 2 & 0.17 & 0.05 & 0.70 & 0.71 & 1.18 & 1.26 \\
\hline 3 & 0.37 & 0.22 & 0.69 & 1.40 & 1.10 & 2.41 \\
\hline 4 & 0.39 & 0.58 & 0.68 & 2.06 & 1.03 & 3.45 \\
\hline 5 & 0.42 & 0.95 & 0.67 & 2.69 & 0.96 & 4.41 \\
\hline 6 & 0.42 & 1.35 & 0.66 & 3.30 & 0.90 & 5.26 \\
\hline 7 & 0.42 & 1.73 & 0.65 & 3.88 & 0.83 & 6.03 \\
\hline 8 & 0.42 & 2.11 & 0.64 & 4.44 & 0.78 & 6.72 \\
\hline 12 & 0.42 & 3.55 & 0.61 & 6.46 & 0.59 & 8.81 \\
\hline 16 & 0.42 & 4.84 & 0.58 & 8.18 & 0.44 & 10.02 \\
\hline 20 & 0.42 & 6.03 & 0.56 & 9.63 & 0.32 & 10.59 \\
\hline 24 & 0.42 & 7.10 & 0.54 & 10.88 & 0.23 & 10.71 \\
\hline 28 & 0.42 & 8.07 & 0.52 & 11.93 & 0.16 & 10.50 \\
\hline 32 & 0.42 & 8.96 & 0.51 & 12.82 & 0.11 & 10.08 \\
\hline 36 & 0.42 & 9.76 & 0.50 & 13.58 & 0.07 & 9.52 \\
\hline 40 & 0.42 & 10.49 & 0.49 & 14.23 & 0.05 & 8.88 \\
\hline 48 & 0.42 & 11.74 & 0.47 & 15.24 & 0.01 & 7.52 \\
\hline$\infty$ & 0.42 & 17.50 & 0.43 & 18.07 & 0.00 & 0.00 \\
\hline
\end{tabular}

Source: Author's calculations. See text description.

a. After-tax purchase price of capital, $p_{t}$.

b. Unrestricted vector autoregression for investment.

c. $\rho$, which parameterizes the elasticity of substitution in equation 4 , is assumed to equal zero.

d. A 0.1 percent increase in the quarterly discount rate, $R_{t}$, is equivalent to a 40 basis point decrease in the interest rate at an annual rate. The discount rate shock dies out 0.95 per quarter, according to equation $9^{\prime}$.

by the unrestricted vector autoregression for investment..$^{58}$ The second two columns give the responses implied by the model..$^{59}$ As noted above, the model does a good job of replicating the long-run magnitude of the response of capital to purchase price shocks, but it does not replicate

58. In calculating the implications of the vector autoregressions, I again do not follow the standard procedure in the literature. The calculations do not allow any response of output and labor to the shock and hence no feedback from them to investment. If I were to follow the standard procedure in the VAR literature of letting all variables respond to the shock, the response would be substantially overstated because of the strong correlation of the innovations in output, labor, and investment that are not due to the cost of capital shocks. Recall that the purchase price of capital shocks are essentially uncorrelated with the other shocks. Hence, once output and labor are eliminated from the calculation, the issue of orthogonalization of the covariance matrix of the innovations is irrelevant.

59. The results are for the Cobb-Douglas case. 
the short-run timing of the response: the long-run response of the model is about the same as the unrestricted estimate; the responses in the unrestricted estimates are, however, somewhat slower than those implied by the model.

The long-run responses of the capital stock in the unrestricted and model's estimates are, respectively, $\$ 17.50$ billion and $\$ 18.07$ billion in 1982 dollars. Given that the estimated vector autoregression is based on flow rather than stock data, it is perhaps surprising that it so closely replicates the results of the model. The average value of the stock is $\$ 2,238$ billion. The implied elasticity is hence around a third. This represents an economically significant response. Consider this response in light of the changes instituted in 1981. In 1980, the value of the purchase price was 0.65 . In 1985, the value was 0.55 . Most of this 15 percent decline is due to changes in the tax law enacted in 1981 and modified in $1982 .{ }^{60}$ The implication is that in the long run, the increase in the capital stock caused by this drop in the purchase price of capital is about 5 percent. Moreover, the response is fairly quick. According to the unrestricted estimates, half the response of the capital stock occurs in about seven years. The model implies that the response is half complete in four and one-half years. Repealing the investment tax credit and curtailing accelerated depreciation would thus result in an important reduction in the capital stock.

\section{REQUIRED RATE OF RETURN}

The second component of the cost of capital is investors' required rate of return. The model implies little correlation between changes in investment and the required rate of return given the historical variances and correlations of the forcing variables. Nonetheless, it is possible to calculate the implications of the model for a change in the required rate of return. The last two columns of table 9 give the response of the levels of investment and the capital stock to an increase in the required rate of

60. Some of the change occurred because nominal interest rates fell when expected inflation fell. Because the tax code is not neutral to inflation (here because depreciation allowances are based on book values), this channel for the interest rate is appropriately thought of as one operating through the tax code. It should not be confused with the channel through the required rate of return, which reflects real rates. 
return. ${ }^{61}$ The shock is equivalent to a 40 basis point annual reduction in the interest rate. The discount rate follows the dynamics given in equation $9^{\prime}$, so the shock dies out roughly 5 percent each quarter. The response is substantial in the medium run. Indeed, for the first five years it exceeds that of the shock to the purchase price. It then dies out to zero. Clearly, a permanent rate-of-return shock would have a larger, and of course permanent, effect on the capital stock. The long-run elasticity of the stock with respect to a permanent shock is approximately unity. The rate of adjustment to a permanent shock is the same as in table 9. On the other hand, if the shocks to the required rate of return die out rapidly, as estimates based on stock returns imply, the effect would be smaller.

The required rate of return is not an exogenous variable. Hence, calculating the dynamic response of a shock to it does not carry the same information as does calculating the response of a shock to the after-tax purchase price, which is largely set by policy rules. Consequently, the results in table 9 summarize the implications of the model given historical changes in the required rate of return as measured by ex ante changes in after-tax real interest rates. The parameterized demand for capital equations in table 5 do not, however, depend on the historical movements of the required rate of return, except for an estimate of its unconditional mean. Hence, notwithstanding the difficulties in quantifying the general equilibrium movements of the required rate of return, the movements supply valid structural estimates of the importance of the required rate of return in the demand for capital.

\section{Summary}

The model described above features joint movements of output and investment in which shocks to productivity and labor have an important role. In the model, firms maximize the present value of profits, taking price as given. The equilibrium implied by this model is calculated under assumptions about the supply of factors to the firm. The equilibrium dynamics are driven by the supply shocks and by shocks to the compo-

61. Unlike the case of the after-tax purchase price of capital, it is impossible to make a case that the required rate of return is exogenous; I do not report the results of the unrestricted estimates. 
nents of the cost of capital. Both the processes followed by the productivity and labor shocks and the process for the components of the cost of capital can be estimated.

The model generates dynamics and cross-correlations that are fairly consistent with those found in the actual data. It replicates the variability of output and investment and generates the persistence and crosscorrelation of the movements in investment and output even though firms do not face quantity constraints in the output market. Moreover, the model shows the lack of correlation with the investors' required rate of return found in the data. The most serious shortcoming of the model's predictions is its overestimate of the contemporaneous correlation of investment and the purchase price of capital. This overestimate, however, seems more a problem of timing than of magnitude: in the data, there is a moderate, negative correlation between the two, but at a greater lag than the model predicts.

The results are robust to widely differing assumptions about the source of fluctuations in the labor market. Whether the labor market clears as a spot market or is governed by long-term relationships that induce substantial frictions, the link between capital formation, output, and the price of capital goods through the production function remains an important one.

Although the model replicates the lack of correlation of investment and the required rate of return found in the data, it captures the economic importance of the effect on the capital stock of the after-tax purchase price of capital. Despite the large response of investment to output shocks, there remains important scope for government tax policies to affect capital formation. 
APPENDIX

\section{Description of the Data}

ThE DATA UNDERLYING the estimates and the fitting of the model are as described below.

Output $\left(y_{t}\right)$

To measure output, I use gross national product of business in constant 1982 dollars. The deflator of this series is used in constructing the real purchase price of capital.

Investment $\left(I_{t}\right)$

This series is private fixed investment in 1982 dollars. Note that investment is not disaggregated into structures and producers' durable equipment because of the conceptual difficulty in defining the margin between the two. The investment data, together with the other national income and product accounts (NIPA) data used in this paper, are taken from the revision released in December 1985 in the Survey of Current Business. One of the most important definitional changes occurred in the deflation of producers' durable equipment. ${ }^{62}$ Instead of assuming that the price of computers is constant, the Bureau of Economic Analysis (BEA) now assumes that it falls sharply, reflecting improvements in quality. The correlations of the estimated effect of purchase price on capital with investment were the same in the newly revised data and in data available immediately before the revision.

Capital $\left(K_{t}\right)$ and Depreciation $(\delta)$

Estimates of the average capital stock and average depreciation rate are required to calculate the implications of the model (but not in the estimation). An average rate of depreciation of 0.024 a quarter is implicit in the BEA's net capital stock figures when one takes the gross flows from the NIPA. (I carry out this calculation on pre-December 1985

62. See "A Note on the Revision of Producers' Durable Equipment," Survey of Current Business, vol. 65 (December 1985), pp. 16-17. 
revision data because the revised capital stock figures have not yet been released.) The real 1982 dollar capital stock is calculated using the standard recursion and the BEA's nominal gross stock figure for 1982 as a benchmark.

Labor $\left(L_{t}\right)$

Labor input is measured as man-hours of private employees from the Bureau of Labor Statistics index in the productivity data. This index is scaled by the number of workers using the 1972 table $6.8 \mathrm{~B}$ from the NIPA.

\section{After-Tax Purchase Price of Capital $\left(p_{t}\right)$}

The after-tax purchase price of capital equals the real price corrected for the special tax treatment of capital expenditures. It is calculated as

$$
p_{t}=P_{t}\left\{1-\tau_{t}\left[\omega P V C C A E_{t}+(1-\omega) P V C C A S_{t}\right]-\omega I T C_{t}\right\},
$$

where

$P_{t}=$ the ratio of the deflator for fixed investment divided by the deflator for output

$\tau_{t}=$ the statutory federal corporate income tax rate plus the average state tax rate

$\omega=$ the average share of producers' durable equipment in total fixed investment

$P V C C A E_{t}=$ the present discounted value of depreciation allowances for producers' durable equipment

PVCCAS $S_{t}=$ the present discounted value of depreciation allowances for structures

$I T C_{t}=$ the investment tax credit rate.

The present discounted value of depreciation allowances and the investment tax credit rate are calculated by Data Resources, Inc.

Required Rate of Return $\left(R_{t}\right)$

The investors' required rate of return is calculated as a discount rate, so

$$
R_{t}=1 /\left(1+r_{t} / 100\right) .
$$

The return, $r_{t}$, is calculated as the real after-tax return on three-month 
Table A-1. Bond Yields and Personal Tax Rates, 1954-84

Percent

\begin{tabular}{|c|c|c|c|c|c|c|}
\hline \multirow[b]{3}{*}{ Year } & \multirow{2}{*}{\multicolumn{2}{|c|}{ Bond yields }} & \multicolumn{4}{|c|}{ Tax rates } \\
\hline & & & \multirow[b]{2}{*}{ Implicit $^{\mathrm{c}}$} & \multirow[b]{2}{*}{ Statutory ${ }^{\mathrm{d}}$} & \multirow{2}{*}{$\begin{array}{l}\text { State and } \\
\text { local }^{\mathrm{e}}\end{array}$} & \multirow[b]{2}{*}{ Fitted $^{\mathrm{t}}$} \\
\hline & Municipal $^{\mathrm{a}}$ & Corporate $^{\mathrm{b}}$ & & & & \\
\hline 1954 & 2.04 & 2.90 & 29.73 & 91.00 & 0.39 & 26.16 \\
\hline 1955 & 2.18 & 3.05 & 28.69 & 91.00 & 0.43 & 26.20 \\
\hline 1956 & 2.50 & 3.36 & 25.54 & 91.00 & 0.47 & 26.24 \\
\hline 1957 & 3.10 & 3.88 & 20.27 & 91.00 & 0.49 & 26.26 \\
\hline 1958 & 2.92 & 3.79 & 22.88 & 91.00 & 0.51 & 26.27 \\
\hline 1959 & 3.35 & 4.38 & 23.58 & 91.00 & 0.58 & 26.35 \\
\hline 1960 & 3.26 & 4.41 & 26.00 & 91.00 & 0.63 & 26.40 \\
\hline 1961 & 3.27 & 4.35 & 24.77 & 91.00 & 0.67 & 26.44 \\
\hline 1962 & 3.03 & 4.32 & 30.04 & 91.00 & 0.72 & 26.48 \\
\hline 1963 & 3.06 & 4.26 & 28.15 & 91.00 & 0.73 & 26.50 \\
\hline 1964 & 3.09 & 4.40 & 29.86 & 77.00 & 0.80 & 31.10 \\
\hline 1965 & 3.16 & 4.49 & 29.58 & 70.00 & 0.81 & 31.72 \\
\hline 1966 & 3.67 & 5.13 & 28.48 & 70.00 & 0.92 & 31.82 \\
\hline 1967 & 3.74 & 5.51 & 32.16 & 70.00 & 1.00 & 31.90 \\
\hline 1968 & 4.20 & 6.17 & 32.04 & 75.25 & 1.17 & 31.73 \\
\hline 1969 & 5.45 & 7.03 & 22.44 & 77.00 & 1.33 & 31.63 \\
\hline 1970 & 6.12 & 8.04 & 23.88 & 71.75 & 1.37 & 32.24 \\
\hline 1971 & 5.22 & 7.39 & 29.31 & 70.00 & 1.46 & 32.36 \\
\hline 1972 & 5.04 & 7.21 & 30.15 & 70.00 & 1.83 & 32.74 \\
\hline 1973 & 4.99 & 7.44 & 32.94 & 70.00 & 1.80 & 32.70 \\
\hline 1974 & 5.89 & 8.57 & 31.22 & 70.00 & 1.77 & 32.67 \\
\hline 1975 & 6.42 & 8.83 & 27.21 & 70.00 & 1.80 & 32.71 \\
\hline 1976 & 5.65 & 8.43 & 32.97 & 70.00 & 1.92 & 32.83 \\
\hline 1977 & 5.20 & 8.02 & 35.21 & 70.00 & 2.00 & 32.90 \\
\hline 1978 & 5.51 & 8.72 & 36.79 & 70.00 & 2.04 & 32.94 \\
\hline 1979 & 5.92 & 9.63 & 38.54 & 70.00 & 1.97 & 32.88 \\
\hline 1980 & 7.85 & 11.94 & 34.28 & 70.00 & 1.97 & 32.87 \\
\hline 1981 & 10.42 & 14.17 & 26.45 & 69.13 & 1.97 & 32.86 \\
\hline 1982 & 10.87 & 13.79 & 21.12 & 50.00 & 2.01 & 26.44 \\
\hline 1983 & 8.80 & 12.04 & 26.92 & 50.00 & 2.14 & 26.57 \\
\hline $1984 \mathrm{~g}$ & 9.61 & 12.71 & 24.40 & 50.00 & 2.14 & 26.57 \\
\hline
\end{tabular}

Sources: Bond yields are taken from Moody's Industry Manual and Municipal and Government Manual; statutory tax rates are from Joseph Pechman, Federal Tax Policy, 4th ed. (Brookings, 1983), table A-1. Remaining columns are calculations by the author. Figures are rounded.

a. Moody's AAA municipal bond yield.

b. Moody's AAA corporate bond yield.

c. One minus the ratio of municipal to corporate bond yields.

d. Maximum federal income tax rate from Pechman, Federal Tax Policy.

e. Ratio of state and local income tax receipts to personal income, from national income and product accounts.

f. Sum of state and local tax rates and fitted value from regressing the implicit rate on a constant, the statutory tax rate, and the square root of the statutory tax rate.

g. The fitted value for 1983-84 is used for 1985 . 
Treasury bills, including a risk premium that equals the average excess holding return of the Standard and Poor's 500 over the Treasury bills. Hence,

$$
r_{t}=\left(t b_{t}+\mu\right)\left(1-\eta_{t}\right)-\pi_{t},
$$

where $t b_{t}$ is the nominal yield on three-month Treasury bills (quarterly rate) in the first month of the quarter, $\mu$ is the average excess return of the Standard and Poor's 500 over Treasury bills, $\eta_{t}$ is an estimate of the representative investor's marginal tax rate, and $\pi_{t}$ is the actual rate of inflation from time $t$ to time $t+1$. Inflation is measured using the deflator for gross domestic product of business, $y_{t}$. The estimated tax rate, $\eta_{t}$, is constructed as follows: the tax rate implied by the ratio of the yields of municipal and corporate bonds is regressed on a constant and the level and square root of the maximum statutory tax rate. The fitted values are added to the average state and local tax rate to obtain $\eta_{t}$. Table A-1 gives $\eta_{t}$ (column 6) and the data used in the calculation.

In calculations based on the long rate, $t b_{t}$ is replaced by the holding period return on Moody's BAA Corporate Bonds. The holding return is

$$
h_{t}=c b_{t}-\left(c b_{t+1}-c b_{t}\right) / c b_{t+1},
$$

where $c b_{t}$ is the nominal yield on the bonds. ${ }^{63}$ Note that a one-period return is appropriate in this context because $R_{t}$ discounts the return between time $t$ and time $t+1$.

63. See Mankiw, “The Term Structure,"' equation 3, in this volume. 


\section{Comments and Discussion}

Olivier J. Blanchard: The discrepancy between theory and empirical work is perhaps nowhere in macroeconomics so obvious as in the case of the aggregate investment function. Matthew Shapiro's paper, which attempts to make sense of the joint movement of investment, output, and the cost of capital using a tight theoretical construct, is therefore welcome.

Let me start by joining Shapiro in expressing my concerns about existing empirical investment equations. The theory from which the neoclassical investment function was initially derived implies that one should be able to specify the model equally well whether using only factor prices or using output and the user cost of capital. We all know that this is not the case. Even if one extends the initial derivation to allow firms to take output as given or not fully adjust price to marginal cost, it is very hard to make sense of the distributed lag of output on investment. It is hard to understand in particular why fluctuations in sales that are in part transitory affect investment decisions with such force, given the time it takes to put capital into operation. My own attempts to explain the lag structure as a convolution of expectational, delivery, and cost-of-adjustment lags have been singularly unsuccessful. ${ }^{1}$ Finally, it is well known that to get the user cost to appear at all in the investment equation, one has to display more than the usual amount of econometric ingenuity, resorting most of the time to choosing a specification that simply forces the effect to be there.

Boldness and new ideas about the investment equation are badly needed. And boldness we get. Let me first summarize the thrust of the paper in a simple way and then offer an assessment.

1. See Andrew Abel and Olivier Blanchard, "Investment and Sales: An Empirical Study," Working Paper (Harvard University, 1983). 
We can think of firms as acting competitively in both goods and labor markets and as being affected by three types of shocks: real wage shocks, user cost shocks, and productivity shocks. Each of these shocks will have different dynamic effects on output and investment. The short- to medium-run effects of favorable shocks are summarized below.

$\begin{array}{lcc} & \begin{array}{c}\text { Effect } \\ \text { on output } \\ \text { positive }\end{array} & \begin{array}{c}\text { Effect on } \\ \text { investment }\end{array} \\ \text { Real wage shocks } & \text { positive } \\ \text { Real user cost shocks } & \text { none } & \text { positive } \\ \text { Productivity shocks } & \text { positive } & \text { positive }\end{array}$

The time frame is that in which shocks can affect investment but capital is not substantially changed. In Shapiro's paper and empirical work, this time is taken to be a year.

A favorable shock to wages (that is, a decrease) leads firms to increase employment and output right away, the increase being determined by the degree of substitution between capital and labor. By increasing profitability, the wage shock also leads to higher investment, although the fact that labor is relatively less expensive leads firms to decrease the optimal capital-labor ratio. A favorable user cost shock (that is, a decrease) has no effect on output, as capital is fixed. But it does increase investment by decreasing the relative price of capital. Finally, a favorable productivity shock increases output as it increases the marginal product of labor.

This is a bare-bones version of the model that Shapiro estimates. Thus, he is able to give estimates both of the variance of the shocks and of the way they affect output and investment. His main conclusion is that real wage and productivity shocks play roughly an equal role, in terms of their contribution to the unconditional variance of output and investment, and that real user cost is unimportant.

This conclusion allows him to explain some of the puzzling correlations between the variables at which he looks. First, both real wage shocks and real productivity shocks create a strong positive correlation between output and investment; but correlation is not causation, and there is no sense in which output movements explain investment as they do under the traditional interpretation. Second, because user cost disturbances play such a small role, the correlation between user cost and investment is small; but this in no sense implies that changing the user cost, through changes in taxation for example, would have no effect on investment. 
Shapiro could have drawn two further conclusions. The first, which he mentions briefly but which deserves better billing, is that if productivity shocks affect anticipated real interest rates, then the correlation between investment and user cost might be positive; put another way, when user cost is used in an investment equation, it is positively correlated with the omitted productivity variable and thus appears insignificant, and may have the wrong sign. He excludes this possibility a priori in his empirical work by assuming saving to be perfectly elastic and the interest rate to be exogenous. This seems unnecessarily restrictive. The second conclusion is that if productivity shocks increase both the demand for labor and the real wage, real wages will be correlated with productivity; again, real wage effects may not show up in an investment equation because of the same omitted variable bias. Both conclusions may explain why factor prices do so poorly at explaining investment.

Shapiro's scenario is an attractive one and seems to reconcile nicely the neoclassical theory of investment with empirical investment behavior. How convincing is it? Let me focus on two main issues, the role and importance of productivity shocks and the role and interpretation of real wage shocks, and deal briefly with two minor issues, the use of first differences and the role of user cost in investment.

Shapiro estimates productivity shocks as residuals from an admittedly crude aggregate production function, in which output depends positively on last year's capital and this year's employment and negatively on this year's investment, with no further lags. There is little doubt that these residuals include much more than productivity shocks; the residuals must be a hodgepodge of true productivity changes, omitted lagged variables, aggregation error, and the like. They are indeed quite large, implying a 4 percent standard deviation in the unexpected movement in productivity over a year. While one may decide to call a residual a productivity shock, the issue involves more than semantics; if the residual includes much more than true Hicks-neutral technical progress, there is little reason to expect investment to respond to this residual in the way suggested by the paper.

But even if these residuals were truly productivity shocks, the view that the shocks come as surprises to firms, leading to unexpectedly high output and to increased investment, is not fully convincing. To take an example, consider the invention of the transistor, mentioned in the paper. The invention may well have been partly unexpected, but it surely 
did not show up in the residual of the production function in the quarter in which it was invented. Technology cannot be changed overnight. What most likely happened is that over time firms decided to invest in transistorized technology. As this technology was slowly put in use, productivity slowly increased. This was no surprise to firms, who expected productivity to increase when they put the new technology in place. To generalize, productivity shocks may be surprises to the econometrician; to firms they are more likely to be largely the planned result of past investment decisions. This has an important implication. Under Shapiro's interpretation, productivity shocks generate a strong positive contemporaneous correlation between output and investment. Under what I find a more reasonable interpretation, productivity shocks generate a strong positive correlation between investment today and output later; they cannot in any way explain the high contemporaneous correlation between investment and output found in the data.

Productivity shocks surely affect growth. They probably have an effect on investment that has not been well captured by previous investment functions. They may explain why we have a hard time finding effects of factor prices on investment. But they are unlikely to explain the strong positive contemporaneous correlation between output and investment.

Real wage shocks, or labor supply shocks as they are called in the paper, may come, in the framework of the paper, either from demand disturbances that increase the price given the wage, leading to a decrease in real wage and higher output, or from shifts in labor supply that affect the equilibrium real wage. Thus, as Shapiro indicates, his model of investment is consistent with equilibrium or disequilibrium in the labor market.

But is it reasonable to explain the shocks as shocks to labor supply? Remember that shocks here are simply deviations of labor supply from a constant, so that all the movement in employment is explained as shocks. To explain all movement in employment as unexplained taste shocks is surely unappealing and unconvincing. Attempts to explain them as optimal intertemporal substitution have not been overwhelmingly successful. So one is drawn to conclude that what we are seeing are mostly demand shocks.

This conclusion, however, only raises further issues, which require covering well-traveled but relevant ground. Output movements in re- 
sponse to aggregate demand shocks should, in this framework of decreasing returns to labor, be associated with lower real wages, but there is by now substantial evidence that this is not the case. ${ }^{2}$ (As Shapiro indicates, simply looking at the correlation of real wages and output is not good enough in the presence of productivity shocks. His decision not to look at real wages also allows him not to confront that issue.) To a close approximation, demand shocks appear to affect output without much affecting real wages. Thus, although Shapiro refers to labor supply shocks as affecting both output and investment, it would be more accurate to describe them as aggregate demand shocks affecting output and investment, without much affecting the wage. This part of the paper is surely less exotic, and much closer to the standard story of output affecting investment, than it appears.

I conclude by taking up two minor points. The first is that of systematic first differencing of the data to take care of nonstationarity. Shapiro is right that past estimation has paid insufficient attention to nonstationarity and that deterministic detrending is probably the source of spurious cyclicality. But estimating the vector autoregressions in terms of first differences may not be the appropriate way to handle it. To take an example, the vector autoregression estimated in table 3 has four of the five variables expressed as first differences. This specification would be appropriate if there were four different sources of nonstationarity in the data, or more technically, four unit roots in the vector autoregression. But if we believe that there is, for example, only one underlying source of nonstationarity, such as productivity, then the vector autoregression is misspecified: it cannot be the reduced form of any structural model. If there are fewer than four unit roots, one can either estimate the system in levels, which gives consistent estimates but with nonstandard distributions of estimates, or use cointegration. This is more than just econometric nit-picking. I strongly suspect that some of the short dynamics found in the paper are the result of too much first differencing.

My final comment has to do with what we learn from the paper about the role of user cost in investment. The paper may give the impression to the casual reader that it explains why the coefficient on the user cost in standard investment equations is insignificant and that it finds a strong

2. See, for example, Mark Bils, "The Cyclical Behavior of Marginal Cost and Price", (Ph.D. dissertation, MIT, 1985). 
effect of the user cost in the data. Both impressions would be wrong. The paper finds a small correlation between investment and user cost, but the finding is due to the small variance of the user cost. The regression coefficient of investment on user cost, which is equal to the correlation of investment and user cost multiplied by the ratio of the standard deviation of investment to the standard deviation of user cost, would still be large and significant if the world were like Shapiro's model. Thus, Shapiro does not explain why the coefficient on the real user cost is neither large nor significant in actual investment equations, though as already mentioned, a correlation between productivity shocks and interest rates could explain that. The paper does not find but in fact postulates an effect of user cost on investment, very much like traditional investment functions. The elasticity of capital to user cost follows from the specification of the production function; the data are allowed to determine only the speed of adjustment of capital to its optimal value and the process for the user cost. While the findings in table 9 on the dynamic effects of user cost are extremely interesting, one must keep in mind that a good part of the response derives from a priori assumptions of the model, not from the data.

In the end, one is tempted to conclude that the paper recasts traditional results in new clothes. But this would be partly unfair. Shapiro's focus on productivity shocks and their effect on investment is the right one, and further research in this direction might eventually explain some of the mysterious features of investment behavior.

Michael C. Lovell: A paper on investment deserves to be evaluated in terms of a rich variety of criteria:

-Does the paper rest on a firm micro foundation?

- How well does it cope with problems of aggregation?

- How well does the model predict relative to the alternatives?

-Are the policy conclusions convincing?

-What is innovative about the analysis, and what are the implications for future research?

These five criteria are demanding. In the current state of the art, no empirical research on investment behavior can hope to earn five stars.

Matthew Shapiro's analysis, like many studies of investment behavior, rests on secure micro foundations, in the sense that the model of the 
firm is derived from the assumption of maximizing behavior in a competitive environment rather than being based on empirical observation as to how firms actually behave in practice. Shapiro's firm is a price taker, buying inputs and selling its product in a perfectly competitive environment; the supply of capital goods and the supply of saving are perfectly elastic; the firm produces under constant returns to scale. As a consequence, the size of the representative firm is indeterminant in the long run, which means that the model would not be appropriate for a study of micro data on investment behavior by individual firms. The adjustment of Shapiro's firm is not instantaneous, however, because of costs of adjustment that are incorporated into the production function. Specifically, when the firm undertakes more investment at any given time, its output is reduced, given the quantities of the inputs.

Obviously, this is not an accurate description of what actually happens. While Shapiro's representative firm can expand only by the purchase of new equipment, enterprises in fact consider acquisitions as an alternative mode of expansion and worry about the threat of takeover. Most firms sell their products in monopolistic competitive, rather than perfect, markets; they are price setters rather than price takers; therefore, shifting market shares may have a great deal to do with how rapidly a particular firm will expand. By abstracting from the complication of imperfect markets, Shapiro creates a problem of the indeterminacy of firm size that places an excessive burden on costs of adjustment.

Part of the cost of rapid expansion arises inside the enterprise: adding a new wing to the factory, reorganizing factory layout, or installing new machinery is likely to be temporarily disruptive. But costs of adjustment may also be external to the firm, reflecting factors outside the factory. Large orders for machine tools and so forth may lead to a lengthening of delivery lags; rapid expansion may make it necessary to approach new suppliers and may generate higher prices for capital equipment, which is not purchased in perfect markets. The marginal efficiency of capital is above the marginal productivity of capital.

Because Shapiro's analysis places excessive reliance on Marshall's time-worn concept of the representative firm, it does not cope well with questions of aggregation. Perhaps the next stage in this line of analysis will be to model individual industries and fit them together into a largescale macroeconometric model.

As to the question of the model's ability to predict investment 
behavior, I think the model will attract more attention if Shapiro takes the time to evaluate its predictive ability relative to the competition.

Prediction cannot be judged only in terms of the ability to predict within and outside the sample period. One can also ask how well the model predicts the general cyclical characteristics of the economy. A complete model should do so, and simulations of the model should have the general features of the business cycle. This strategy, emphasized by Finn Kydland and Edward Prescott, is also considered by Shapiro. ${ }^{1}$ Looking at the dynamic implications of a set of assumptions as well as asking whether they are consistent with maximizing behavior is a fruitful application of Samuelson's "Correspondence Principle."'2 From the point of view of evaluating automatic stabilizers and shifts in policy rules, this is the appropriate way to proceed. Indeed, when this is the objective, one might sacrifice some of the traditional goodness-of-fit in order to calibrate the model in a way that will generate the essential features of the cycle. It might be more appropriate to conduct the analysis in the frequency domain than in terms of correlograms, in part because of the superiority of spectral estimation techniques and in part because of ease of interpretation. A partial step in this direction would be to translate the estimated serial correlations into the frequency domain.

This strategy is not without precedent. I have applied it myself in a multisector study of the inventory cycle in which I left out fixed investment entirely, as has I.R.M. Bain. ${ }^{3}$ This application was probably a mistake, and it is equally inappropriate to get too excited about the question of whether Shapiro's model generates a reasonable cycle, given that it leaves out such major cyclical components as consumption and inventories as well as the complications created by the reactions of policymakers to inflation and the political business cycle. Because an embarrassing variety of models may be capable of generating more or

1. Finn E. Kydland and Edward C. Prescott, "Time to Build and Aggregate Fluctuations,"' Econometrica, vol. 50 (November 1982), pp. 1345-70.

2. Paul Anthony Samuelson, Foundations of Economic Analysis (Harvard University Press, 1947), p. 258.

3. Michael Lovell, "Buffer Stocks, Sales Expectations, and Stability: A Multi-Sector Analysis of the Inventory Cycle,"' Econometrica, vol. 30 (April 1962), pp. 267-96. See also I.R.M. Bain, " A Theory of the Cyclical Movement of Inventory Stocks, ' unpublished paper presented at the December meetings of the Econometric Society, New York, 1985. 
less realistic business cycles, this line of attack will yield convincing results only when it is applied to more complete models capturing the essential features of our complex economy.

Are the policy conclusions reached by Shapiro convincing? In contrast to Kydland and Prescott, who left out the monetary sector, Shapiro gives monetary variables a chance, but finds they do not matter appreciably. ${ }^{4}$ The chance is provided by using the Treasury bill rate, with an added constant risk premium, as the lever by which monetary policy does its work. A longer term rate might be more revealing, because it would allow the firm to lock up the cost of funds over the life of the investment, if only in nominal rather than real terms. The author should determine whether the policy conclusions are robust or whether they are sensitive to the choice of a particular measure of the opportunity cost of borrowed funds.

The heart of Shapiro's contribution is his analysis of supply shocks, which influence both output and investment. Such shocks, if we were talking about agriculture, might reflect the weather, but of course they also represent technological change. Robert Solow taught us long ago how to estimate the shocks of technological progress, and it may well be fruitful to see whether estimates derived with his residual procedure help in explaining investment behavior. It might also be useful to try to use investment equations and the production function simultaneously in generating improved estimates of the latent productivity shock variable. In such an undertaking it would be appropriate to ask whether the supply shocks should be treated as exogenous or whether in fact the pace of innovation is conditioned, as Joseph Schumpeter pointed out, by the phase of the business cycle.

Shapiro's paper is a brave step forward in a difficult area that has received detailed attention from sophisticated scholars over a number of years. My concerns about his paper are equally applicable to much of the research in this area. While I think that Shapiro's paper constitutes incremental progress in the state of the art, it also illustrates how far we will have to go before we have a thorough understanding of the determinants of investment behavior.

4. Kydland and Prescott, "Time to Build." 


\section{General Discussion}

Robert Hall pointed out that an extensive body of research had identified much of the cyclical variation in measured productivity as the result of rational labor hoarding by firms in the face of negative demand shocks. He did not believe that Shapiro's modeling of productivity, $\epsilon$, had adequately allowed for these effects. Robert Gordon added that part of the changing relationship between aggregate output and inputs comes from changes in the composition of aggregate output. Thus as output shifts temporarily away from a high-productivity industry, such as automobile manufacturing, aggregate productivity falls. The changing mix of output, together with labor hoarding, accounted for much of Okun's law. Both of these demand shock effects would also be an important part of Shapiro's $\epsilon s$.

Hall raised the question of whether the changes in Shapiro's $\epsilon$ could possibly be interpreted as random innovations to productivity. $\mathrm{He}$ observed that the $\epsilon S$ vary enormously, with implied productivity changes of plus or minus 1 percent a quarter not unusual, and argued that shocks that come readily to mind, such as the weather, natural disasters, and technological innovation, are not sufficiently variable to cause productivity fluctuations of this magnitude. Technological innovation, which has large long-run effects, is gradually diffused into the production process and does not have random positive and negative impacts. William Nordhaus, although not accepting the particular way Shapiro had modeled productivity shocks, observed that long-term trends in productivity are not well accounted for by conventional variables such as research and development spending or investment. The poor U.S. productivity performance since 1973 may be attributable to supply shocks from many sources that cannot be readily quantified but that may be reflected in part in Shapiro's $\epsilon$.

Gregory Mankiw observed that Shapiro is not alone in failing to identify the sources of hypothesized shocks. Macroeconomists are accustomed to allowing for unobservable shocks to aggregate demand. Discussions of monetary policy during the early 1980 s refer frequently to "velocity shocks." Hall has argued that shocks to the consumption function account for roughly a third of variation in output over the 
business cycle. Apart from whether Shapiro's attempt to identify them in quarterly data was successful, Mankiw concluded that it may be as reasonable to allow for unobservable productivity shocks as it is to allow for unobservable demand shocks.

James Tobin pointed out that two sorts of supply shocks ought to be distinguished: shocks to the aggregate production function, which affect investment and output in the same direction, and shocks to the marginal productivity of capital, which may affect output and investment in opposite directions. For example, the shock to oil prices in the 1970s had a negative effect on output but arguably increased the marginal productivity of capital by making it worthwhile for oil-using industries to invest in energy-saving technology. Insofar as supply shocks are of the latter sort, it is more difficult to use them to explain the contemporaneous positive correlation between output and investment.

Hall pointed out that the absence of a positive correlation between investment and the price of capital-one of the puzzles Shapiro set out to unravel-can easily be accounted for by shifts in the investment function from whatever source, and does not require recourse to the kind of productivity shocks Shapiro hypothesized. For example, if "animal spirits" are an important determinant of investment, increases in investment may be associated with increases in both the interest rate and the price of capital goods.

Alan Blinder questioned Shapiro's assumption of quadratic adjustment costs. He found it implausible that, for example, the disruption associated with installing seven new machine tools could be forty-nine times as large as the disruption associated with installing one new machine tool. George von Furstenberg suggested that Shapiro overstated the cost of capital by ignoring the tax deductibility of interest payments. He conjectured that this overstatement could be quite large during periods of high inflation.

Gordon responded to Shapiro's suggestion that growth in investment might help to explain why measured productivity begins to decline before the end of business-cycle expansions, noting that not all postwar endof-expansion periods fit this characterization. Although an end-ofexpansion drop-off in productivity was observed in both 1956 and 1979, the ratio of investment to GNP was unusually high only in 1956.

Nordhaus drew attention to the substantial lags between changes in the price of capital goods and changes in investment in Shapiro's model. 
He regarded the putty-clay nature of capital investment as one reason for the lags. Another is that changes in price must lead to revised appropriation decisions that in turn take time to be implemented. In Nordhaus's view, one of the important messages of Shapiro's paper is that previous studies may have missed the significant effect of capital prices on investment decisions in large part because they did not allow for sufficient lags. 